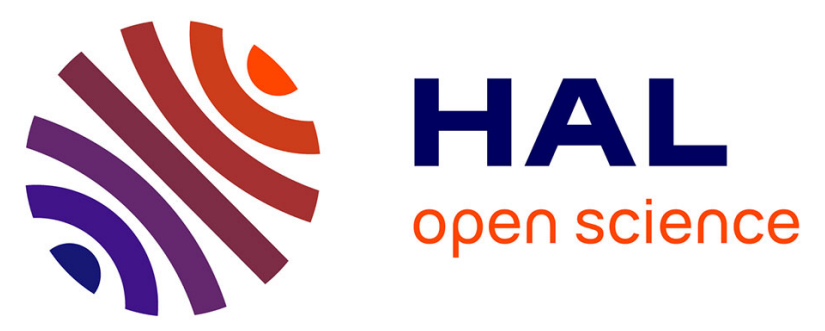

\title{
Anatolia: a long-time plant refuge area documented by pollen records over the last 23 Million years
}

Demet Biltekin, Speranta-Maria Popescu, Jean-Pierre Suc, Pierre Quézel, Gonzalo Jiménez-Moreno, Nurdan Yavuz, M Namik Çağatay

\section{- To cite this version:}

Demet Biltekin, Speranta-Maria Popescu, Jean-Pierre Suc, Pierre Quézel, Gonzalo Jiménez-Moreno, et al.. Anatolia: a long-time plant refuge area documented by pollen records over the last 23 Million years. Review of Palaeobotany and Palynology, 2015, 215, pp.1-22. 10.1016/j.revpalbo.2014.12.004 . hal-01108700

\section{HAL Id: hal-01108700 \\ https://hal.science/hal-01108700}

Submitted on 23 Jan 2015

HAL is a multi-disciplinary open access archive for the deposit and dissemination of scientific research documents, whether they are published or not. The documents may come from teaching and research institutions in France or abroad, or from public or private research centers.
L'archive ouverte pluridisciplinaire HAL, est destinée au dépôt et à la diffusion de documents scientifiques de niveau recherche, publiés ou non, émanant des établissements d'enseignement et de recherche français ou étrangers, des laboratoires publics ou privés. 


\title{
Anatolia: a long-time plant refuge area documented by pollen records over the last 23 Million years
}

\author{
Demet Biltekin ${ }^{1}$, Speranta-Maria Popescu ${ }^{2}$, Jean-Pierre Suc ${ }^{3-4 *}$, \\ Pierre Quézel $^{5}$, Gonzalo Jiménez-Moreno ${ }^{6}$, \\ Nurdan Yavuz ${ }^{7}$, M. Namık Çağatay ${ }^{1}$
}

${ }^{1}$ Istanbul Technical University, Faculty of Mines, Eastern Mediterranean Centre for Oceanography and Limnology (EMCOL), Ayazaga Campus, 34469 Istanbul, Turkey. Present address: Institut Catala de Paleoecologia Humana i Evolucio Social (IPHES), Zona Educacional 4, Building W3, Campus Sescelades, 43007, Tarragona, Spain.

${ }^{2}$ GeoBioStratData.Consulting, 385 route du Mas Rillier, 69140 Rillieux la Pape, France

${ }^{3}$ Sorbonne Universités, UPMC Univ. Paris 06, UMR 7193, Institut des Sciences de la Terre Paris (iSTeP), 75005 Paris, France.

${ }^{4}$ CNRS, UMR 7193, Institut des Sciences de la Terre Paris (iSTeP), 75005 Paris, France.

${ }^{5} 395$ chemin du Cabrol, 13360 Roquevaire, France.

${ }^{6}$ Departamento de Estratigrafía y Paleontología, Universidad de Granada, Fuenta Nueva S/N, 18002 Granada, Spain.

${ }^{7}$ General Directorate of Mineral Research and Exploration, Department of Geological Research, Dumlupınar Boulevard 139, 06800 Çankaya/Ankara, Turkey.

\begin{abstract}
North and South Anatolia areas are today refuge areas for plants that were previously widespread in the European and Mediterranean regions. Thirteen well-dated Anatolian pollen records spanning the last 23 million years allow for a reconstruction of the history of several plants that have disappeared from this region or are surviving in this refuge area. For example, in this study we show that Cedrus is an ancient element of the Anatolian flora. Tropical elements lived in this area until the early Pliocene. Subtropical elements became extinct in the Middle to Late Pleistocene, except for Glyptostrobus (Taxodiaceae swamp tree) and Carya (Juglandaceae, a warm-temperate tree), which may have persisted until recently in this area. In addition, a comparison of palaeofloras coming from different locations ranging from $36-38^{\circ} \mathrm{N}$ and $40-42^{\circ} \mathrm{N}$ latitudinal intervals in the northeastern Mediterranean (including Anatolian coastal regions) with those from Europe and North Africa has been done. This shows that the North and South Anatolia areas appear to have been separate refuges for thermophilous-hygrophilous plants since the early Pliocene ( $c a$. 5 Million years). Today, Anatolia is a plant refuge area for warmtemperate species, which have almost completely (Zelkova) or completely (Pterocarya, Liquidambar, Parrotia persica) disappeared from other European and peri-Mediterranean regions. Taxodiaceae swamp ecosystems (Glyptostrobus) might have recently disappeared from the southern Black Sea shoreline. New pollen data from Anatolia also allowed us in calibrating the timing of floristic extinctions at a continental scale and helped us in clarifying the reasons of the different floral extinctions and dynamics (breaking up and shifting) in the refuge areas. Thanks to global warming there is a potential for the survival and expansion of thermophilous species (Pterocarya fraxinifolia, Zelkova abelica, Liquidambar orientalis) in this area.
\end{abstract}




\section{Keywords}

Plant refuges, Pollen, late Cenozoic, Anatolia

\section{Highlights}

$>$ Pollen records from Anatolia show succession of plant extinctions since $23 \mathrm{Ma} .>$ North and South Anatolia are separated refuges for thermophilous/hygrophilous plants since $5 \mathrm{Ma}$. $>$ Glyptostrobus swamps recently disappeared from the southern Black Sea shoreline. $>$ Cedrus has been a continuous component of the Anatolian flora since at least $23 \mathrm{Ma}$.

\section{*Corresponding author :}

Jean-Pierre Suc, Institut des Sciences de la Terre Paris (ISTEP), UMR 7193, Laboratoire Evolution et Modélisation des Bassins Sédimentaires, Université P. et M. Curie - Paris 6, 75005 Paris (France), jeanpierre.suc@gmail.com

\section{Introduction}

Thermophilous and hygrophilous flora from southern Europe and the southern Mediterranean area (including the Near East) has suffered a lot of extinctions during the late Cenozoic. These extinctions have been documented by plant macrofossils (Follieri, 2010; Follieri et al., 1986; Kovar-Eder et al., 2006) and, for the most part, by pollen records (Suc et al., 1995b; Suc and Popescu, 2005; Jiménez-Moreno and Suc, 2007; Jiménez-Moreno et al., 2007; Leroy, 2007; Magri, 2010). Two major steps of extinction have been identified at 14 million years (Ma) and 3.4 Ma (Suc et al., 1999, 2004). The first step corresponds to a global decrease in temperature (Zachos et al., 2001), moderately recorded in the Mediterranean region (Fauquette et al., 2007), during which the most thermophilous plants disappeared from the northern coastlines (JiménezMoreno and Suc, 2007; Jiménez-Moreno et al., 2007), in a context already characterized by a strong latitudinal increase in dryness (Fauquette et al., 2007; Jiménez-Moreno and Suc, 2007). The second step corresponds to a minor global climatic cooling (Shackleton et al., 1995) that in the Mediterranean region was more characterized by an increase in dryness and enhanced seasonal contrast (Suc, 1984; Suc et al., 1995b; Popescu et al., 2010).

According to the plant classification by Nix (1982), five plant groups can be differentiated according to the mean annual temperature (MAT) under which they grow:

- megathermic (tropical): MAT $>24^{\circ} \mathrm{C}$;

- mega-mesothermic (subtropical): $20^{\circ} \mathrm{C}<\mathrm{MAT}<24^{\circ} \mathrm{C}$;

- mesothermic (warm-temperate): $14^{\circ} \mathrm{C}<\mathrm{MAT}<20^{\circ} \mathrm{C}$;

- meso-microthermic (cool-temperate): $12^{\circ} \mathrm{C}<\mathrm{MAT}<14^{\circ} \mathrm{C}$;

- microthermic (boreal): MAT $<12^{\circ} \mathrm{C}$.

Most of the megathermic taxa disappeared from the northern Mediterranean shorelines during the early Serravallian (14 Ma) and a large number of mega-mesothermic plants became extinct in this region at $c a$. 3.4 Ma (Suc et al., 1999, 2004). Since then, the remaining mega-mesothermic (Taxodiaceae, Nyssa p.p.), mesothermic elements (Liquidambar, Pterocarya, Carya, Nyssa p.p., Zelkova p.p.) and meso-microthermic to microthermic elements (Cathaya, Cedrus, Tsuga), requiring high precipitation, persisted in some reduced areas during a certain time according to 
latitude, altitude, differences in slope exposure and microclimate (Suc et al., 1995b; Suc and Popescu, 2005).

Taxa that disappeared from southern Europe belong to several families. For example: (1) megathermic plants: Leguminosae, Sapindaceae, Bombacaceae (Bombax), Verbenaceae (Avicennia), Euphorbiaceae (Alchornea, Amanoa), Sapotaceae; (2) mega-mesothermic plants: Hamamelidaceae (Distylium, Hamamelis, Fothergilla), Lauraceae, Juglandaceae (Engelhardia, Platycarya), Taxodiaceae, Arecaceae; (3) mesothermic plants: Hamamelidaceae (Liquidambar, Parrotia), Juglandaceae (Carya, Pterocarya); (4) meso-microthermic plants: Cathaya (coniferous today restricted to China; Wang, 1961) and (5) microthermic plants: Tsuga and Cedrus. Timing and causes of these extinctions are generally explained by successive coolings in the northern hemisphere and Mediterranean aridification since $c a .14$ Ma. This resulted in two present-day refuge areas on longitudinal fringes in the Mediterranean (Suc et al., 2004). For example, Zelkova, Pterocarya and Liquidambar remained in the northeastern Mediterranean region. Laurus and Argania (Sapotaceae) remained in the southwestern Mediterranean region. Cedrus persisted in both regions (Quézel and Médail, 2003). Pterocarya fraxinifolia and Liquidambar orientalis are the only thermophilous trees that persisted in Anatolia (coastlines and nearby slopes). Anatolia then appears as the most important refuge area (Zohary, 1973; Quézel and Médail, 2003) as shown by its high plant diversity (Médail and Diadema, 2009).

In this study we address the following questions: is the refuge status of Anatolia recent or was acquired in the past? Was this area subject to successive floral extinctions since the past $14 \mathrm{Ma}$ due to climatic change? Otherwise, is Anatolia characterized by the same floral history as other Mediterranean regions? Pollen can help us in answering these questions. However, in this region, pollen studies were traditionally performed without a robust botanical background and as such have been poorly useful in this way (Nakoman, 1967; Benda, 1971; Akgün and Akyol, 1999). Since the 2000's, we have been performing an intensive effort in the botanical identification of late Cenozoic pollen grains from Anatolia, allowing for more detailed information about vegetation changes. In this synthesis, we compare new pollen records (Fig. 1a) from twelve sites (discontinuous documentation of the Miocene and early Pliocene) and a long core, DSDP Site 380 (continuous record of the last $6 \mathrm{Ma}$ from southwestern Black Sea), with pre-existing pollen data from Europe and North Africa.

\section{Current vegetation and flora of Anatolia}

\subsection{Vegetation}

Present-day vegetation of Anatolia is complex and relates to the Mediterranean, IranoTouranian, European and Euxino-Hyrcanian phytogeographic regions (Fig. 1c; Denk, 1998).

The West and South coastal areas are characterized by the Mediterranean realm, which also sporadically characterizes the North shoreline and some encased valleys within the Pontic Ranges. Several bioclimates and altitudinal vegetation belts have been defined according to rainfall and altitude (Quézel and Médail, 2003): a thermo-Mediterranean belt with Olea europea and Pistacia lentiscus where Ceratonia is scarce; some riparian forests with Liquidambar orientalis and Platanus orientalis; a meso-Mediterranean belt characterized by sclerophyllous oaks, where Quercus ilex is very rare; a supra-Mediterranean belt inhabited by deciduous associations including Carpinus orientalis and Ostrya carpinifolia; a Mediterranean montane belt composed of altitudinal conifers with Cedrus libani occupying significant areas on the Taurus and Anti-Taurus massifs and an oro-Mediterranean belt characterized by meadows and steppes. 
The Irano-Touranian region, encompassing the Anatolian Plateau, is affected by annual precipitations lower than $200 \mathrm{~mm}$. A diversified steppe vegetation, where Artemisia is relatively subsidiary, occurs in this area (at least to the West). Pre-steppic structures less subject to human impact with trees (Pinus pallasiana and Juniperus excelsa westward, Quercus libani, Q. brantii eastward) only appear on reliefs where precipitations are higher.

The European region is secondary in Anatolia, and is only represented by some deciduous hilly stands with Quercus and Carpinus betulus.

The Euxino-Hyrcanian region, characterized by high precipitations and the lack of summer drought, develops along the Black Sea shoreline. There, wonderful hilly forests still exist, dominated by deciduous elements (mostly Quercus hartwissiana, Q. macranthera, Carpinus betulus, Castanea sativa, Fagus orientalis, Rhodendrum ponticum, Rh. flavum). Riparian forests also occur, with Alnus, Fraxinus, and Pterocarya. The montane belt is mainly occupied by Fagus orientalis and Rhododendron ponticum, with occurrences of Abies nordmanniana, and Picea orientalis restricted to the East. The subalpine and alpine belts are mainly developed to the East where influence of Caucasus relief prevails within a diversified flora (Juniperus communis and $J$. sabina coexist with several Ericaceae).

\subsection{Anatolia: present-day plant refuge area}

Anatolia is today a refuge area of Neogene and early Pleistocene Mediterranean flora. Some mesothermic Eurasian taxa such as Liquidambar, Parrotia, Pterocarya, Zelkova and Cedrus (microthermic tree) persisted through the European Neogene and can still be found in reduced areas in the Anatolian landscape and in the Hyrcanian zone (Quézel and Médail, 2003). Zelkova crenata occurs today in two very restricted riparian localities in easternmost Anatolia, close to the Van Lake, although it is still well developed in Abkhazia, Small Caucasus, and mainly in the Hyrcanian region (Zohary, 1973). In addition, this genus is still present in very restricted areas of Crete (Z. abelicea) and Sicily (Z. sicula) (Di Pasquale et al., 1992). Liquidambar orientalis occurs in different areas (Fig. 1b). The vastest extension is located in the riparian forests of the southwesternmost Anatolia (area of Köyceğiz-Marmaris) but can also be found in northeastern Antalya (Akman et al., 1993). The third occurrence area is located along the Oronte River, close to Hatay. The two last localities significantly shortened since the Hellenic time during which ancient documents indicate that Liquidambar was abundant and intensely used for producing styrax (Amigues, 2007). Pterocarya fraxinifolia is still present in riparian forests along the Black and Marmara seas, being relatively abundant in the latter (Fig. 1b). It is also recorded in some localities near the Iskenderun Gulf (Fig. 1b). This tree also occurs in the above-mentioned Anatolian regions where Zelkova is living. Cedrus libani seems to be better distributed (Quézel and Médail, 2003): it abounds on the Taurus and Anti-Taurus massifs, although it is declining today (Fig. 1b). Few reduced populations persist on the back slope of the Pontic Ranges (region of Erbaa-Niksar; Fig. 1b).

To summarize, the present-day plant refuges in Anatolia are located on both latitudinal edges (Fig. 1b), between $42^{\circ}$ and $40^{\circ} \mathrm{N}$ (Pterocarya fraxinifolia) and $38^{\circ}$ and $36^{\circ} \mathrm{N}$ (Liquidambar orientalis and Cedrus libani), respectively. We must recall that Pterocarya fraxinifolia and Zelkova carpinifolia are also growing today in the nearby western Transcaucasia (Colchis plant refuge area; Denk et al., 2001).

\section{Methods and materials}

In this study, 786 pollen samples have been analysed from 13 sections (Fig. 1a): Ermenek, Burhanl, Eceabat (D. Biltekin), İntepe (D. Biltekin and J.-P. Suc), Avadan and Karayayla (J.-P. 
Suc), Site 380 (S.-M. Popescu, D. Biltekin, S. Boroi, J.-P. Suc), Seyitömer, Güven, Bayramhacılı, Akdağ, Güzelöz (N. Yavuz), Çatakbağyaka (G. Jiménez-Moreno) (Figs. 2, 3).

\subsection{Pollen analysis}

About 20-30 g of dry sediment was processed using acids (HCl35\%, HF70\%). Then, palynomorphs were concentrated using $\mathrm{ZnCl}_{2}$ (density $>2$ ) and through sieved (10 $\left.\mu \mathrm{m}\right)$. The final pollen-rich residue was mounted in glycerol. An almost similar technique but adding $\mathrm{KOH}$ to some samples was used for the localities Güvem, Akdağ, Seyitömer, Bayramhacıll, and Güzelöz (Yavuz-Işık, 2007, 2008; Yavuz-Işık and Toprak, 2010).

Pollen analyses result from counting a minimum of 150 pollen grains, excluding Pinus. A special effort was done in the botanical identification of pollen grains from late Cenozoic sediments since the 1970's under the initiative and training of one of us (J.-P.S.). For this purpose, a very accurate attention was done to pollen morphology with a continuous comparison between past and present pollen grains. The latter are examined from modern plant pollen grain collections. Their photographs were systematically indexed and a corresponding database has been developed, which benefits from continuous updating. Some regional photograph atlases (Europe, Southeastern Asia, Mediterranean) of modern pollen grains have also been regularly consulted. Scanning Electronic Microscope has been used for comparative examination of some past and modern pollen grains. This effort gave to the authors a very extensive experience in pollen morphology and knowledge of the past peri-Mediterranean pollen floras. In this study, we pay special attention to selected (often thermophilous/hygrophilous) taxa that have disappeared from Anatolia (Avicennia, Sapotaceae, Arecaceae, Cathaya, Taxodiaceae, Nyssa, Engelhardia, Tsuga, Carya, Zelkova, Parrotia persica) or are still present in the region (Cedrus, Liquidambar, Pterocarya) (Figs. 2, 3).

Fluorescence microscopy is commonly used as a reliable reworking index (Havinga, 1967; van Gijzel, 1967; Philips, 1972; Doláková and Burešová, 2007): “with increasing age and for a single type of palynomorph, the colours shift from blue-green, white or yellow and strong fluorescence to orange, red or brown and weak fluorescence". In order to test reliability of the Taxodiaceae pollen from the upper part of the series $(2 \mathrm{~m}, 30.51 \mathrm{~m}, 49.47 \mathrm{~m}, 169.16 \mathrm{~m})$, we performed a comparative examination using fluorescence microscopy also including samples from the middle and lower parts of the series $(334.50 \mathrm{~m}$ : Middle Pleistocene; $976.99 \mathrm{~m}$ : late Miocene) where Taxodiaceae pollen is clearly not reworked. In the uppermost samples, comparison has been extended to Artemisia pollen which cannot be regarded as reworked. Examination was done using an AX10 Lab.A1 Zeiss microscope where fluorescence intensity has been adjusted between 56 and 72 .

\subsection{Pollen localities}

The considered (twelve outcrops, one core) sections are dated by various methods (Figs. 2, 3). The Ermenek lacustrine sediments are ascribed to lower Miocene according to mammals and freshwater ostracods, being overlain by late Burdigalian marine deposits (Ilgar and Nemec, 2005). These sediments, deposited close to the sea level, have been uplifted (up to about $1000 \mathrm{~m}$ ) since the middle Miocene. In the Güvem Basin, lacustrine diatomites and clays are exposed at ca. $1500 \mathrm{~m}$ in altitude and dated by Burdigalian mammals. They are inbedded within volcanic deposits comprised between about $20 \mathrm{Ma}$ (base) and $18 \mathrm{Ma}$ (top; Yavuz-Işık, 2008). The fluviolacustrine deposits of Çatakbağyaka (altitude: $500 \mathrm{~m}$ ) are dated as Langhian after studying their mammal content (Sickenberg et al., 1975; Heissig, 1976). The Seyitömer series (ca. $1100 \mathrm{~m}$ in altitude) is also dated by mammals (Yavuz-Işık, 2007): its lower part (coal) is younger than 18 Ma (upper Burdigalian), its upper part is older than 11 Ma (Serravallian; Sen, 1997). The age of 
the clayey pollen localities from the relatively high area of Nevşehir (Akdağ: $1100 \mathrm{~m}$; Bayramhacılı: $1000 \mathrm{~m}$; Güzelöz: $1500 \mathrm{~m}$ ) is indicated by radiometry of associated ignimbrites: range of the Akdağ pollen flora is 9-8.3 Ma, that of Bayramhacilı 7.6-6.8 Ma, that of Güzelöz 4.5-3 Ma (Yavuz-Işık and Toprak, 2010). The low pollen floras of Burhanlı (12 m), Eceabat (60 $\mathrm{m}$ ) and İntepe $(180 \mathrm{~m})$ come from marine clays dated by calcareous nannoplankton, from late Tortonian to earliest Zanclean (Melinte-Dobrinescu et al., 2009). The marine shale layers from Avadan (altitude: $110 \mathrm{~m}$ ) and Karayayla (altitude: $150 \mathrm{~m}$ ) are dated as early Zanclean according to planktonic foraminifers (Nazik, 2004). DSDP Site 380 (water depth: $2107 \mathrm{~m}$ ) benefits from a robust calcareous nannoplankton biostratigraphy calibrating the high-resolution climatostratigraphy provided by the pollen record, which allows precise relationships with the reference oxygen isotope curve (Popescu et al., 2010). As a consequence, robust ages since $6 \mathrm{Ma}$ are indicated in Figure 3.

\section{Pollen floras}

Pollen assemblages of the new localities are shortly reviewed to inform on their floristic content and vegetation significance. Variability is also indicated according to their geographic location and age.

\subsection{Ermenek (early Miocene)}

The Ermenek flora (Figs. 1a, 2) includes few pollen grains of very scarce megathermic elements (Sapotaceae, Euphorbiaceae, Rubiaceae) accompanied by some mega-mesothermic elements especially in the upper part of the section (Taxodiaceae, Engelhardia). Mesothermic elements (Carya, Pterocarya, Liquidambar, Zelkova ${ }^{1}$ ) are frequent to abundant in some samples. Cathaya is frequent in the lowermost part of the section, Cedrus is continuously abundant despite decreasing percentages at the top, both probably originating from the nearby Central Taurides. The Ermenek palaeolake was bordered by mesophilous forests replaced in altitude by coniferous woodlands dominated by Cedrus (with Cathaya, Tsuga, Abies, Picea). The continuous record of Artemisia suggests the early occurrence of steppe environments in this area.

\subsection{Güvem (early Miocene)}

This pollen flora (Figs. 1a, 2; Yavuz-Iş1k, 2008) is characterized by few megathermic taxa (Sapotaceae) and frequent mega-mesothermic plants (Cyrillaceae-Clethraceae, Taxodiaceae, especially Engelhardia). Carya is dominant among mesothermic trees with occurrences of Pterocarya and Liquidambar. Meso-microthermic (Cathaya) and microthermic (Cedrus) conifers are rarely represented, suggesting that no high relief existed at $18 \mathrm{Ma}$ in this volcanic area. A mesophilous forest probably occurred around the Güvem palaeolake. Open environments were not important.

\subsection{Seyitömer (early-middle Miocene)}

This pollen flora (Figs. 1a, 2; Yavuz-Işık, 2007) includes very few megathermic (Sapotaceae) and mega-mesothermic (Taxodiaceae, Engelhardia) taxa. Carya, Pterocarya, Zelkova, Liquidambar and Parrotia persica are among the main mesothermic plants. Cathaya is present and Cedrus is very abundant, suggesting high-elevation conifer forest growing on nearby

\footnotetext{
${ }^{1}$ Note that Zelkova has only been considered as present when the when the pollen-analyst distinguished it from
} 
mountain ranges. The local vegetation was a swamp forest during the Burdigalian (coal deposits) replaced by a mesophilous forest later on in the Langhian (clayey deposits). Conifer forest grew in altitude.

\section{4. Çatakbağyaka (middle Miocene)}

This pollen flora (Figs. 1a, 2; Jiménez-Moreno, 2005; Jiménez-Moreno et al., 2007) is highly diversified. This is shown by the occurrences of several megathermic (Euphorbiaceae, Rubiaceae, Sapotaceae, Alchornea, Passifloraceae, Acacia) and mega-mesothermic (Arecaceae, Celastraceae, Distylium, Engelhardia, Taxodiaceae) taxa and agrees with its assignment to the warmest phase of Miocene. Mesothermic plants include Carya, Pterocarya, Liquidambar, Zelkova, and Parrotia persica. Cedrus and Cathaya also occur, denoting some elevated relief in the region. Herbs constitute a significant part of the pollen assemblage indicating relatively open environments.

\subsection{Nevsehir area: Akdăg, Bayramhacíl, Güzelöz sections (late Miocene-early Pliocene)}

Three pollen floras document this time-interval in the central Anatolia Plateau: Akdağ, Bayramhacílı and Güzelöz (Figs. 1a, 2, 3; Yavuz-Işik and Toprak, 2010). The Akdağ pollen flora includes few mesothermic plants (with Pterocarya, Parrotia persica). Cedrus occurs in low percentages. A similar composition characterizes the Bayramhacílı pollen flora where only Carya and Liquidambar are present among the mesothermic plants. Tsuga, Cathaya and Cedrus occur in low percentages in this pollen record. Pterocarya is present at Güzelöz. Artemisia and other herbaceous pollen are abundant in these localities, documenting the ancient development of Anatolian steppes on the plateaus (Yavuz-Işik and Toprak, 2010).

\subsection{The Dardanelles Strait area: Burhanl, Eceabat, İntepe sections (late Miocene-earliest Pliocene)}

Three pollen floras document this time-interval in the Dardanelles Strait area: Burhanl, Eceabat and İntepe (Figs. 1a, 2, 3; Melinte-Dobrinescu et al., 2009). Mega-mesothermic plants are represented by low percentages of Engelhardia and Taxodiaceae. Carya, Pterocarya, Liquidambar and Zelkova are relatively frequent among the mesothermic plants. Altitudinal trees are represented by Cathaya, Cedrus, Abies and Picea. Their percentage increases significantly after the Messinian Salinity Crisis, well recorded in this area through fluvial erosion. This increase in altitudinal plants probably results from the uplift of the Ganos-Gelibolu Massif as a response to the blocking of the North Anatolian Fault before its propagation (Armijo et al., 1999; Melinte-Dobrinescu et al., 2009). The coastal area was characterized by open vegetation (Melinte-Dobrinescu et al., 2009).

\subsection{Avadan and Karayayla (early Pliocene)}

Plant diversity of the Avadan and Karayayla coastal pollen floras (Figs. 1a, 3; JiménezMoreno et al., 2007) is low, with Sapotaceae and Taxodiaceae as the only megathermic and mega-mesothermic representatives respectively. Mesothermic plants Pterocarya, Liquidambar and Zelkova also occur. Cathaya and Cedrus are present, coming from the Central Taurides mountain range. Local coastal vegetation was characterized by herbaceous plants.

\subsection{Site 380 (late Miocene to Present)}


DSDP Site 380 is a unique deep marine long pollen record covering the last $6 \mathrm{Ma}$ (Figs. 1a, 3; Popescu, 2006; Popescu et al., 2010; Biltekin, 2010).

The simplified pollen diagram can be subdivided into three parts from the diversity viewpoint:

- ca. 6-3.37 Ma, 1020-703 m below the sea floor (bsf): forested vegetation dominated despite some forest retreats due to coolings marked by the initial expansion of Artemisia steppe (Popescu, 2006). Megathermic taxa were sporadic (Avicennia, Sapotaceae, Amanoa, Fothergilla, Sapindaceae, Acanthaceae). Mega-mesothermic plants were abundant (with mainly Taxodiaceae in large percentages, Engelhardia, Arecaceae, Nyssa, Distylium, Microtropis fallax). Mesothermic abounded (particularly deciduous Quercus, Carya, Pterocarya, Liquidambar, Zelkova, Parrotia persica). Cathaya and also Tsuga and Cedrus were almost continuously recorded, indicating the presence of high-elevation mountain ranges near the Black Sea shore.

- 3.37- ca. 1.22 Ma, 703-319 m bsf (Biltekin, 2010): most of the megathermic plants disappeared, except for Avicennia recorded at $412 \mathrm{~m}$. This decrease in megathermic species is specifically well marked at $703 \mathrm{~m}$, corresponding to the cooling at $3.37 \mathrm{Ma}$ (Popescu et al., 2010). Another well-marked decrease in thermophilous species occurred at 2.62 Ma. This one was related to the earliest glacial cooling in the Northern Hemisphere (Popescu et al., 2010). This event was characterized by:

$\circ$ among the mega-mesothermic taxa: disappearance of Arecaceae, almost complete extinction of Nyssa, and strong decline in Engelhardia and Taxodiaceae;

- among the mesothermic plants: disappearance of Parrotia persica, strong decline in Liquidambar, and weakening of Carya, Pterocarya and Zelkova;

- scarcity of the meso-microthermic conifer Cathaya (despite a short interval of almost continuous record between 649 and $638 \mathrm{~m}$ );

- relative strengthening of Tsuga and Cedrus (microthermic conifers).

This interval was characterized by the alternation between mesophilous forest (warm phases) and steppes (cool phases) enriched in Artemisia at the onset of the 41 kyr North Hemisphere climatic cycles. Interglacials were characterized by peaks of deciduous Quercus and Taxodiaceae (Glyptostrobus) (Fig. 3). Taxodiaceae pollen grains were probably favoured in the water transport because these trees inhabited coastal areas where they extended during those warm periods (Popescu et al., 2010).

- $\quad 1.22 \mathrm{Ma}-$ Present, $319 \mathrm{~m}$ bsf-hole top. There was a supremacy of Artemisia steppes over mesophilous forests whatever the climatic phase, glacial or interglacial. This vegetation characterized a period of progressive replacement $(350-300 \mathrm{~m})$ of the $41 \mathrm{kyr}$ climatic cycles by $100 \mathrm{kyr}$ cycles (Popescu et al., 2010). The survival of Taxodiaceae in this area is a crucial question to be discussed. Thermophilous taxa present a generally regressive trend:

- Engelhardia progressively became rare and disappeared at $86 \mathrm{~m}$. Taxodiaceae declined too during glacials but increased during interglacials up to practically disappear during the Last Glacial $(30-17 \mathrm{~m})$. Taxodiaceae reappeared at the Holocene but progressively declined up to Present;

- Carya, Pterocarya, Liquidambar and Zelkova disappeared too;

- Cathaya discontinuously reappeared (219-114 m depth) while Cedrus and mostly Tsuga became rarer.

\section{Plant extinctions in the Northeastern Mediterranean region}


Floral changes for the past $23 \mathrm{Ma}$ are described in this study through a review of pollen records from the Northeastern Mediterranean area. This concerns thirty two more pollen records besides the ten ones described above. They are located within and nearby the North latitude intervals $36^{\circ}-38^{\circ}$ (SALI $=$ South Anatolia latitudinal interval) and $40^{\circ}-42^{\circ}$ (NALI $=$ North Anatolia latitudinal interval) (Fig. 4a, Table 1), where present-day plant relicts occur (Fig. 1b). We only used localities characterized by a reliable chronology and where pollen was classified using a botanical identification. We selectively used macrofloras to support the presence or absence of some taxa. The taxa selected for this review are those that are reliably identified in all the pollen floras: Avicennia, Sapotaceae, Arecaceae, Nyssa, Engelhardia, Carya, Cathaya, Tsuga, Taxodiaceae (non Sciadopitys), including those still living in Anatolia (Pterocarya, Liquidambar, Cedrus) or nearby (Zelkova, Parrotia persica). This comparison greatly benefited from the long Site 380 pollen record. We distinguished three classes of plants: those which do not grow today in the Northeastern Mediterranean region, those still occurring near Anatolia and those still growing in Anatolia. These plant's dynamics were examined and compared to the present-day geographic distribution of their living representatives.

\subsection{Taxa today absent from the Northeastern Mediterranean region}

The occurrence at Site 380 of occasional pollen grains of Avicennia at about $6 \mathrm{Ma}, 4.8 \mathrm{Ma}$ and 1.6 $\mathrm{Ma}$ is noteworthy (Figs. 3, 4b). Evidences of this mangrove tree on the northern Anatolian shoreline at 6 and $4.8 \mathrm{Ma}$ are consistent with the presence of other megathermic taxa (Amanoa, Fothergilla, Exbucklandia, Sapindaceae, Loranthaceae, Acanthaceae; Popescu, 2006). The record of a single pollen grain at $c a$. 1.6 Ma is more questionable. Was Avicennia still growing in the area or is it an unusually very well-preserved reworked pollen? We must thus imagine a protected North Anatolian coastline with a propitious salinity context at least up to $3.37 \mathrm{Ma}$, or even later. In this region, occurrence of Avicennia is documented in the early Oligocene at Pullukcu, NW Turkey (İslamoğlu et al., 2010) and in the middle Miocene at Satovcha, SW Bulgaria, by one of us (J.-P.S.) in a floral context including Passifloraceae, Sapindaceae and Meliaceae (D. Ivanov, personal information). A Langhian occurrence of Avicennia has been recently reported by Kayseri-Özer (2014) on the Aegean Turkish shoreline near Kultak - Muğla - Milas area in the SALI (i.e., ca. $37^{\circ} \mathrm{N}$ latitude) without complete information on the data (Figs. 4a, 4c). Later, only the occasional records from Site 380 support the presence of Avicennia in the region. The presence of Sapotaceae is scarcely documented in Anatolia and at Site 380 up to the earliest Pliocene (Figs. 2, 3, 4b). Sapotaceae were found in the NALI at Ptolemais (Northern Greece; Figs. 4a-b, Table 1) up to ca. 4 Ma (Ioakim, 1984) ${ }^{2}$. Their extinction occurred at $c a$. 1.7 Ma in the SALI in the Citadel section (Zakynthos Island; Figs. 4ac, Table 1; Suballyova et al., 1999; Subally et al., 1999).

Nyssa has not been recorded in the Anatolian Neogene (Fig. 2). It is scarcely documented between 6 and 5.6 Ma at Site 380 with other three limited occurrences at ca. 4.7 Ma, ca. 1.25 Ma and $c a .850 \mathrm{ka}$ (Figs. 3, 4b). It is very rare in the NALI, with discontinuous occurrences up to about $4 \mathrm{Ma}$ as documented at Ptolemais $^{2}$ (Fig. 4b; Ioakim, 1984). In the SALI, only the central Greece Mavradzei locality (12-11 Ma; Ioakim and Solounias, 1985) records Nyssa except for a brief occurrence at Zeli in the Samos Island (lower Pleistocene; Ioakim and Rondoyani, 1988) (Figs. 4a, 4c, Table 1).

Engelhardia is continuously recorded in Anatolia and abundant up to $c a .1 .25$ Ma at Site 380 (Figs. 2, 3). It decreased later on and its last occurrence is recorded at Site 380, within the Middle Pleistocene at $c a .200$ ka (Figs. 3, 4b). Other NALI localities do not document its presence later than $4 \mathrm{Ma}$ (last occurrence at Ptolemais'2: Ioakim, 1984; Biltekin, 2010) (Fig. 4b),

\footnotetext{
${ }^{2}$ Chronology based on correlations with magnetostratigraphy of Van Vugt et al. (1998).
} 
while those of the SALI show its presence up to $1.7 \mathrm{Ma}$ at the Citadel of Zakynthos (Suballyova et al., 1999; Subally et al., 1999) (Fig. 4c).

Taxodiaceae display two pollen types (Erdtman, 1965): pollen of Sciadopitys has a unique morphology; pollen grains with an appendix (papilla) characterize the other genera (Sequoia, Taxodium, Glyptostrobus, Metasequoia, Cryptomeria, Cunninghamia, Taiwania, Sequoiadendron, Athrotaxis). The latter taxa are abundant in the sediments of Site 380 and usually found in the other studied localities (Figs. 2, 3). Identification of their pollen grain is possible at the genus level on the basis of (1) the size and shape of papilla and (2) the distribution and density of glomeruli constituting the sculpture observed at the scanning electronic microscope (Reyre, 1968; Jinxing and Yuxi, 2000). Pollen grains of Taxodiaceae from Site 380 show these morphological characters under the light microscope. This is confirmed at the scanning electronic microscope for many specimens from several samples (Plate I). The comparison at the scanning electronic microscope of the fossil pollen grains with pollen grains of the different Taxodiaceae genera shows that the Taxodiaceae pollen grains from Site 380 mostly belong to Glyptostrobus (Plate I, 1-4). This identification is in agreement with the many occurrences of Glyptostrobus europaeus in the Neogene macrofloras from the region (Kasapligil, 1977; Velitzelos and Gregor, 1990; Gemici et al., 1991; İnci, 2002). As discussed by Popescu et al. (2010), Glyptostrobus should have inhabited swamps along the southern Black Sea coastline during the last $6 \mathrm{Ma}$. Glyptostrobus went through two severe declines at about 1.2 and $0.5 \mathrm{Ma}$ (Fig. 3), but might have survived in this area until recently. Within the NALI, only Site 380 documents persistence of Taxodiaceae later than $4 \mathrm{Ma}$ (recorded at the top of the Ptolemais ${ }^{2}$ series: Fig. 4b; Ioakim, 1984; Kloosterboer-van Hoeve, 2000; Biltekin, 2010). In the SALI, Taxodiaceae are recorded up to $c a$. $1 \mathrm{Ma}$ at Tsampika (Figs. 4a, 4c, Table 1; Joannin et al., 2007). A priori, the record of Taxodiaceae pollen at Site 380 until the Holocene might be considered as resulting from reworking, as this family is absent today from the region. However, Taxodiaceae pollen grains are well-preserved throughout the section, particularly in the uppermost levels (Plate I, 11-12). In addition, Site 380 has been cored in a deep basin (2107 m of water depth) where input of terrigenous sediments by rivers is relatively weak. Sedimentation rate at Site 380 since $2.62 \mathrm{Ma}$ (beginning of the glacial-interglacial cycles) is only $26 \mathrm{~cm} / \mathrm{kyr}$ on average, which is very different from the $58 \mathrm{~cm} / \mathrm{kyr}$ for the last $520 \mathrm{ka}$ at hole PRGL1-4 in the Gulf of Lions (NW Mediterranean), mostly fed in terrigenous sediments by the Rhône River (Suc et al., in progress). Here, obviously reworked pollen grains represent at maximum 5\% of the pollen content in present-day sediments (Beaudouin et al., 2007), less than 7\% in sediments cored at hole PRGL1-4 for total pollen concentration generally lower than 2,000 grains/g of sediment. At Site 380, obviously reworked pollen grains are less than 3\% for a total pollen concentration that comprised between 3,000 and 20,000 grains/g of sediment (Popescu, 2001). This comparison suggests that potentially reworked pollen grains at Site 380 are few.

Moreover, Taxodiaceae percentages at Site 380 covary with the mesothermic trees as illustrated by deciduous Quercus in Figure 3. Since 1 Ma (i.e. the uppermost $230 \mathrm{~m}$ of the series), glacial-interglacial alternations are more pronounced and Taxodiaceae percentages decreased significantly. Peaks in deciduous Quercus reflect warm phases (i.e., interglacials; Fig. 3 ) and it is almost continuously recorded and beyond suspicion of reworking. If resulting from reworking, Taxodiaceae pollen should have been expected to show an opposite pattern than that of deciduous Quercus, with maxima occurring during glacials when the Black Sea level dropped and land erosion and fluvial transport of reworked pollen grains were probably optimal according to the scenario developed by Lericolais et al. $(2009,2013)$ for the Last Climatic Cycle. Pollen data contradict such a model for transport and redeposition of Taxodiaceae pollen in the deep southwestern Black Sea during cold phases of the Late Pleistocene and Holocene. In addition, according to its location, Site 380 was not fed in terrigenous sediments by the powerful Danube River (Lericolais et al., 2013) but by short Thrace rivers and predominantly by the 
Anatolian Sakarya River (Fig. 1a). Actually, Taxodiaceae appear to show a fluctuating pattern of progressive extinction within a frame of glacial-interglacial phases up to a very weak residual occurrence during the Holocene (Fig. 3).

At $2 \mathrm{~m}$ and $30.51 \mathrm{~m}$ depth, well-preserved Taxodiaceae pollen grains (Pl. II, Figs. 1, 7) respectively ascribed to Holocene and Late Pleistocene (Fig. 3) show a yellow to orange relatively strong fluorescence (Pl. II, Figs. 2, 8). They cannot be absolutely considered as nonreworked but almost probably autochthonous Artemisia pollen grains (Pl. II, Figs. 3, 9) show a similar response to excitement (Pl. II, Figs. 4, 10). No conclusive interpretation can be expressed from these specimens. Two other similarly preserved Taxodiaceae pollen grains (Pl. II, Figs. 13, 17) have been observed at $169.16 \mathrm{~m}$ depth (Middle Pleistocene). They show a yellow strong fluorescence (Pl. II, Figs. 14, 18) such as pollen of Artemisia (Pl. II, Figs. 15, 16) and must be regarded as autochthonous. At $334.50 \mathrm{~m}$ depth (lower Pleistocene), Taxodiaceae pollen displays a yellow and moderate fluorescence (P1. II, Figs. 19, 20). At last, Taxodiaceae pollen from Messinian (976.99 $\mathrm{m}$ depth) shows a yellowish-orangy relatively weak fluorescence (P1. II, Figs. 21, 22). The observed fluorescence gradient from 976.99 to $169.16 \mathrm{~m}$ depth is in agreement with the age range from Messinian to Middle Pleistocene ( $c a .0 .5 \mathrm{Ma}$ ). Equivalence of both Taxodiaceae and Artemisia with respect to fluorescence unquestionably supports that Taxodiaceae pollen grains are not resedimented. Only authenticity of the uppermost Taxodiaceae specimens could be debated. However, their almost similar even stronger fluorescence compared to that of the Artemisia specimens incline us to consider that they can reflect some residual coastal Late Pleistocene to Holocene communities. We feel that their very good preservation (Pl. I, Figs. 11, 12; Pl. II, Figs. 1, 7) may be regarded as a non-decisive argument. However, the occurrence in Holocene and Late Pleistocene layers of some less preserved Taxodiaceae (P1. II, Figs. 5, 11) pollen with an orangy weak fluorescence (P1. II, Figs. 6, 12) indicates that actually reworked distinguishable specimens are mixed with low quantity well-preserved pollen grains that we have counted as probably non reworked ones.

Therefore, we must objectively consider that occurrence of non-reworked Taxodiaceae pollen grains cannot be neglected in the uppermost layers of Site 380 . The probability is conceivable that relictuous communities of Glyptostrobus have inhabited coastal swamps of the south Black Sea coastline up to until sometime during the Holocene (Fig. 4b). Some cores from the Marmara Sea (MAR98-9: Fig. 4a; Table 1; Mudie et al. 2002; MD01-2430: Valsecchi et al., 2012) and from the southern Black Sea (B7: Fig. 4a; Table 1; Mudie et al. 2002; 22-GC3: Shumilovskikh et al., 2012) provided a pollen flora documenting the Holocene vegetation in the region. These records do not mention Taxodiaceae pollen and, according to the available information, we can propose three possible alternate explanations as follows:

- the analysed cores were too far to the West (Marmara cores) and to the East (Black Sea cores) from the relictual Glyptostrobus localities which could have been confined around the mouth of the Sakarya River (Fig. 1a);

- pollen-analysts may have found Taxodiaceae pollen grains in these records and a priori put them in the stock of reworked pollen, an understandable behaviour for lack of Pleistocene step back that is filled in by our study at Site 380 ;

- at last, pollen-analysts may have been unsure in identifying Taxodiaceae pollen.

At Site 380, Cathaya pollen is relatively abundant during two time-intervals: 6-3 Ma and 950-380 ka (Figs. 3, 4b). Considering the other localities within the NALI, its presence is confirmed at ca. 4 Ma (Fig. 4b) at Ptolemais ${ }^{2}$ (Ioakim, 1984; Kloosterboer-van Hoeve, 2000; Biltekin, 2010). In several other localities, it has not been identified yet as such but it could be present at Tenaghi Philippon ${ }^{3}$ (Northern Greece; Fig. 4a, Table 1) under the names Podocarpus at $c a$. 1.1 Ma and/or Pinus haploxylon type, almost continuously present up to $850 \mathrm{ka}$ and

\footnotetext{
${ }^{3}$ The chronology relative to Tenaghi Philippon is from Tzedakis et al. (2006).
} 
sporadically indicated at $325 \mathrm{ka}, 50 \mathrm{ka}, 30-40 \mathrm{ka}$ (Fig. 4b; Wijmstra, 1969; Wijmstra and Smit, 1976; Van der Wiel and Wijmstra, 1987a). The SALI displays the presence of Cathaya up to at least $1 \mathrm{Ma}$, as documented at Tsampika (Fig. 4c; Joannin et al., 2007).

Carya is almost continuously recorded up to $380 \mathrm{ka}$ and sporadically until ca. $2 \mathrm{ka}$ at Site 380 (Figs. 3, 4b). Within the NALI, the last evidences of Carya at Tenaghi Philippon ${ }^{3}$ are recorded at about $900 \mathrm{ka}$ (Van der Wiel and Wijmstra, 1987b). This contrasts with its occurrence in the core MAR98-9 (eastern Marmara Sea; Fig. 4a, Table 1) during the last 4 ka (Mudie et al., 2002) (Fig. 4b). Carya is rarely documented in the SALI from $4.5 \mathrm{Ma}$ to $1 \mathrm{Ma}$ (last occurrence at Tsampika; Joannin et al., 2007) (Fig. 4c).

Tsuga is continuously recorded at Site 380 up to $1.27 \mathrm{Ma}$ and sporadically found until $230 \mathrm{ka}$ (Figs. 3, 4b). Within the NALI, Tsuga is continuously recorded at Tenaghi Philippon ${ }^{3}$ up to 1.1 Ma and sporadically until 700 ka (Fig. 4b; Van der Wiel and Wijmstra, 1987a, 1987b).

\subsection{Taxa absent today from Anatolia but still living in a nearby region}

Zelkova pollen is not always distinguished from that of Ulmus. We identified Zelkova specimens from Site 380, where it is continuously recorded up to $1.22 \mathrm{Ma}$ and sporadically up to $150 \mathrm{ka}$, using its morphological criterions concerning ectexine: thicknening around the pores and proeminent sculpture (Kuprianova, 1965; Figs. 3, 4b). At Tenaghi Philippon ${ }^{3}$, Zelkova is clearly documented until $450 \mathrm{ka}$ (Van der Wiel and Wijmstra, 1987a), but only mentioned up to $340 \mathrm{ka}$ (Wijmstra and Smit, 1976; Wijmstra, 1969). Tzedakis et al. (2003) show sporadic occurrences of Zelkova during the Last Interglacial between 133 and $115 \mathrm{ka}$ at Ioanina (western Greece; Fig. 4a, Table 1), which would constitute the youngest records in the NALI (Fig. 4b). The presence of Zelkova is undoubtedly documented in the SALI until $0.98 \mathrm{Ma}$, with additional potential occurrences between 650 and $300 \mathrm{ka}$ at Megalopolis (west Peloponnesous; Figs. 4a, 4c, Table 1; Okuda et al., 2002) and last localized robust occurrences between 4 and $3 \mathrm{ka}$ at holes OEN 1 and 2 from the Acheloos Delta (outlet of the Corinth Gulf; Figs. 4a, 4c, Table 1; Fouache et al., 2005). The recent last occurrences of Zelkova pollen in both latitudinal intervals are in agreement with its survival in Crete (Quézel and Médail, 2003), close to Van Lake in southeastern Turkey (see above) and western Transcaucasia (Denk et al., 2001).

Parrotia persica's pollen grain is not frequently identified because its thin membrane (exine) is often poorly preserved (see photographs of modern and fossil pollen grains of $P$. persica in: Naud and Suc, 1975; Bińka et al., 2003; Leroy, 2007). However, it has been reliably recorded up to $3.85 \mathrm{Ma}$ at Site 380 (Figs. 3, 4b). Also it has been reported at Tenaghi Philippon ${ }^{3}$ until $830 \mathrm{ka}$ (Fig. 4b; Van der Wiel and Wijmstra, 1987a, 1987b). P. persica has been found up to $980 \mathrm{ka}$ in the SALI, at Tsampika (Figs. 4c; Joannin et al., 2007). Its retreat to its present populations in few more or less isolated small areas in Iran (Wendelbo, 1968; Sefidi et al., 2011) thus appears to be relatively ancient. Pollen records show the occurrence of Parrotia persica in the southern Caspian region during the entire Holocene (Leroy et al., 2011, 2013).

\subsection{Taxa still living in the Northeastern Mediterranean region}

Arecaceae have been continuously recorded up to $3.37 \mathrm{Ma}$ at Site 380 (Figs. 3, 4b). The youngest occurrence of Arecaceae in the other localities of the NALI is at about 4.2 Ma in the Nestos 2 hole (Figs. 4a-b, Table 1; Drivaliari, 1993; Jiménez-Moreno et al., 2007). In the SALI, Arecaceae (cf. Chamaerops) have been recorded between 4 and $3 \mathrm{ka}$ at holes OEN 1 and 2 from the Acheloos Delta (Figs. 4c; Fouache et al., 2005). Arecaceae survived until today in this latitudinal area. Phoenix is still present in Crete and southern Anatolia (P. theophrasti) and the 
Mediterranean palm Chamaerops humilis occurred in Crete until recently (Quézel and Médail, 2003).

Pterocarya is continuously recorded in Anatolia during the Miocene and Pliocene (Figs. 2, 3). At Site 380, it becomes rare by $1.26 \mathrm{Ma}$ and disappeared at $400 \mathrm{ka}$ (Figs. 3, 4b). At Tenaghi Philippon $^{3}$, it becomes rare at $730 \mathrm{ka}$ and disappeared at $510 \mathrm{ka}$ (Wijmstra and Smit, 1976; Van der Wiel and Wijmstra, 1987a, 1987b). Very interesting is the pollen record from the Black Sea core BS7 (Fig. 4a, Table 1) where Pterocarya is rare until $7 \mathrm{ka}$ and then relatively frequent up to Present (Mudie et al., 2002). Therefore, its occurrence in the NALI is documented until today (Fig. 4b), as also shown by Leroy et al. $(2009,2010)$ in northwestern Turkey. In the SALI, it became rare at $980 \mathrm{ka}$ and disappeared at about $400 \mathrm{ka}$ (Fig. 4c). This is indicated by the Megalopolis pollen record (Okuda et al., 2002) and is consistent with the present residual occurrence area of Pterocarya, larger in northern than in southern Anatolia (Fig. 1b).

Liquidambar pollen records indicate a similar Miocene and Pliocene history than Pterocarya, but it is relatively less abundant (Figs. 2, 3). At Site 380, its almost continuous presence ends at $1.28 \mathrm{Ma}$ and it disappeared at $270 \mathrm{ka}$ (Figs. 3, 4b). It is less abundant in the other localities from the NALI where it disappeared at $480 \mathrm{ka}$ as recorded at Tenaghi Philippon ${ }^{3}$ (Fig. 4b; Wijmstra and Smit, 1976; Van der Wiel and Wijmstra, 1987a, 1987b). In the SALI, Liquidambar pollen is more abundant up to $1 \mathrm{Ma}$ (Tsampika; Joannin et al., 2007) and is not recorded after $300 \mathrm{ka}$ (Megalopolis; Okuda et al., 2002) (Fig. 4C). Liquidambar is not continuously and abundantly documented. This is not surprising, as Liquidambar pollen is underrepresented in the pollen spectra (Brush and DeFries, 1981). Therefore, its absence from both NALI and SALI during the late Quaternary is not in contradiction with its present-day occurrence in southwestern Anatolia and in the island of Rhodes (Fig. 1b).

Cedrus pollen is abundant during the Miocene in Anatolia, particularly at Ermenek (Fig. 2). It is also relatively abundant at İ ntepe (Fig. 3) and Site 380 where it is almost continuously recorded up to $1.27 \mathrm{Ma}$ and more discontinuously occurs until Present (Figs. 3, 4b). Cedrus pollen has been discontinuously to continuously recorded during the Last Glacial in southern Europe where such occurrences have been considered as resulting from long wind transport (Magri and Parra, 2002). Such pollen contaminations may have also affected the uppermost $60 \mathrm{~m}$ of Site 380. However, present-day Cedrus survivals in northern Turkey (Erbaa-Niksar; Fig. 1b) lead to moderate this probability in the region. Cedrus is frequent up to about $4 \mathrm{Ma}$ at Ptolemais ${ }^{2}$ (Ioakim, 1984; Kloosterboer-van Hoeve, 2000; Biltekin, 2010). It is almost continuously recorded up to $1.02 \mathrm{Ma}$ at Tenaghi Philippon ${ }^{3}$ and some occurrences are observed at $700 \mathrm{ka}$ and $570 \mathrm{ka}$ (Wijmstra and Smit, 1976; Van der Wiel and Wijmstra, 1987a, 1987b). Cedrus is present at $8.5 \mathrm{ka}$ at Lake Maliq (Albania; Fig. 4a, Table 1; Denèfle et al., 2000). It discontinuously occurs during the last $10 \mathrm{ka}$ in cores MAR98-9 and BS7 (Mudie et al., 2002). As a consequence, one may consider that Cedrus became rare in the NALI since 1 Ma but may have survived here until very recently (Fig. 4b) as shown by Leroy et al. $(2009,2010)$ in northwestern Turkey. In the SALI, Cedrus pollen is continuously recorded with significant percentages until $1 \mathrm{Ma}$ (Tsampika; Joannin et al., 2007). Percentages decreased later, but it was almost continuously found during the last $48 \mathrm{ka}$ in core C69, with some increases during the 43-36 ka and 25-6 ka intervals (SW Aegean Sea; Fig. 4a, 4c, Table 1; Geraga et al., 2005). The occurrence observed in the Acheloos Delta (core OEN1) at ca. 9 ka (Fouache et al., 2005) is to be considered in this context. Today, Cedrus includes four species: $C$. deodara, $C$. atlantica, $C$. libani and $C$. brevifolia. Their pollen grains show a homogenous morphology, however some distinctive characters have been indicated by Aytuğ (1961): they concern the cappa which is a little thicker in C. deodara, thinner in C. atlantica, with lateral crests in C. libani and C. brevifolia (Plate III, 1-4). Well-preserved Cedrus pollen grains from Anatolia display some homogeneity, with a relatively thick cappa and commonly lateral crests (Plate III, 5-12). A reconstructed Cedrus phylogeny (molecular clock) places the divergence between $C$. atlantica and the couple $C$. libani 
- C. brevifolia at about $19 \mathrm{Ma}$, significantly after that with $C$. deodara (ca. $55 \mathrm{Ma}$ ) and prior to that within the couple C. libani-C. brevifolia (ca. $7 \mathrm{Ma}$ ) (Qiao et al., 2007). Accordingly, we may consider that the Neogene pollen grains of Cedrus recorded in Anatolia refer to the couple C. libani - C. brevifolia for the oldest floras (Ermenek, Catakbağyaka, Seyitömer) and to $C$. libani for the younger ones (İntepe, Site 380). Therefore, Cedrus has continuously been documented in the area for a very long time and validates its long-time continuous abundance on the mountain areas bordering the Anatolian Plateau and its elimination from the northern and western margins by human disturbance. The isolated and scattered populations of Cedrus near Niksar and Erbaa (Fig. 1b), whose origin was questioned by several authors (Pons, 1998; Quézel and Médail, 2003; Boydak and Çalikoğlu, 2008), are probably the remnants of a past larger distribution of Cedrus in northern Anatolia. Therefore, we believe that now there is enough data to support that present-day Cedrus forests were more widespread in the past (Anşin and Küçük, 1990).

\section{Discussion}

\subsection{Compared extinctions in Anatolia, Europe Mediterranean region, and western Transcaucasia}

The past $23 \mathrm{Ma}$ floral history of northern Anatolia is accurately documented by pollen data from this area (Figs. 2, 3), completed by many other localities in the more extended NALI (northern Greece and Bulgaria) (Fig. 4b). Some taxa became extinct from northern Anatolia during the Pleistocene (Engelhardia, Cathaya, Tsuga, Zelkova, Liquidambar) or later on, during the Holocene (Glyptostrobus, Carya) probably related with human disturbance (Fig. 4b). Two taxa, Pterocarya and Cedrus, persisted in this area until today. NALI (Fig. 4a) can be considered as a refuge area at least since the upper Pliocene (occurrences of Avicennia? Nyssa? Engelhardia, Glyptostrobus, Cathaya, Tsuga). Today, climate in coastal northern Anatolia (Şensoy and Ulupınar, 2008) is temperate and humid almost continuously through the year: mean annual temperature comprised between 9 and $15^{\circ} \mathrm{C}$, annual precipitations between 600 and $1200 \mathrm{~mm}$ with a maximum of $2200 \mathrm{~mm}$ to the East. Spring is the season with minimum rainfall. Such conditions are caused by conjugated humid air masses coming from the West and Northwest (Atlantic Ocean) and cold and dry air masses originating from Siberia, which get moisture over the Black Sea. Quantified climatic conditions at $5 \mathrm{Ma}$ according to pollen data from Site 380 indicate a mean annual temperature at $17.3^{\circ} \mathrm{C}$ (range: $15.6-19.8^{\circ} \mathrm{C}$ ) and annual precipitations at $1100 \mathrm{~mm}$ (range: $680-1550 \mathrm{~mm}$ ) (Fauquette et al., 2006). Persistence of the last thermophilous taxa here (including those still present today) such as Engelhardia, Carya, Zelkova and Pterocarya, suggests that temperature and precipitations did not decrease too much in the region (or at least in certain refuge areas) during the Pleistocene glacial stages. Here, we used the present climatic distribution of plant species that occurred in this area during the Neogene in an attempt to delimit the range of climatic parameters during the Quaternary. For example, Engelhardia, the first of the four mentioned plants to disappear (200 ka at Site 380), lives today mainly in China where it requires a mean annual temperature that is comprised between $5.4^{\circ} \mathrm{C}$ and $24.8^{\circ} \mathrm{C}$, a minimum temperature of the coldest month of $-2.1^{\circ} \mathrm{C}$ and mean annual precipitations between 741 and $3495 \mathrm{~mm}$ (Fang et al., 2011). Carya, which was the last to disappear, includes some modern species in North America that tolerate low mean annual temperatures between 2 and $5^{\circ} \mathrm{C}$ (Thompson et al., 2000). Among the four Chinese species, $C$. cathayensis tolerates up to $-0.4^{\circ} \mathrm{C}$ as mean temperature of the coldest month (Fang et al., 2011). The record of Taxodiaceae pollen grains at Site 380 until the Holocene is not problematic either as Glyptostrobus pensilis inhabits today lake shores or marine coastlines in regions of China and 
Vietnam under warm and humid climatic conditions: mean annual temperature around $18.8^{\circ} \mathrm{C}$ (range: $10.6-23^{\circ} \mathrm{C}$ ), mean temperature of the coldest month of $9^{\circ} \mathrm{C}$ (range: $-0.2-15.2^{\circ} \mathrm{C}$ ), mean temperature of the warmest month of $27.6^{\circ} \mathrm{C}$ and an annual precipitation of $1526 \mathrm{~mm}$ (range: 950-2148 mm) (Fang et al., 2011).

The history of the flora in southern Anatolia is discontinuously documented by pollen data from about $23 \mathrm{Ma}$ to $5 \mathrm{Ma}$ (Figs. 2, 3) and is fortunately completed by data from some Quaternary localities in the SALI (southern Greece) (Fig. 4b). Available data are not continuous enough to reconstruct a very complete story of the flora in southern Anatolia as in northern Anatolia. However, pollen data seem to be very reliable and relatively recent pollen records from SALI support the persistence until today of Arecaceae, Liquidambar, Pterocarya and Cedrus. This also applies to Zelkova, which also grows today in Crete and southeastern Turkey (Van Lake) (Fig. 4c). Today, climate of coastal region in southern Anatolia (Şensoy and Ulupınar, 2008 ) is greatly seasonal with mild and humid winters opposed to warm and dry summers: mean annual temperature comprised between 16 and $20^{\circ} \mathrm{C}$ and annual precipitations between 600 and $1400 \mathrm{~mm}$, with some areas between 400 and $600 \mathrm{~mm}$ or even less. Such conditions are controlled by warm and dry air masses coming from North Africa, which can get some moisture over the Mediterranean Sea. The plant relics living at low altitude in southern Anatolia such as Phoenix theophrasti (Arecaceae), Pterocarya fraxinifolia and Liquidambar orientalis find the necessary humidity in riparian forest environments (Quézel and Médail, 2003). On the contrary, Cedrus libani, less demanding of high temperatures, generally grows today between 800 and $2100 \mathrm{~m}$, with mean annual temperature ranging from 6 to $12^{\circ} \mathrm{C}$, where it finds the necessary humidity (annual precipitation: 600-1200 mm with rainless summers) (Boydak and Çalikoğlu, 2008). The higher temperature range requirements of the relictuous populations of Cathaya argyrophylla in southern China (mean annual temperature: $13.4-18^{\circ} \mathrm{C}$; Fang et al., 2011) could contribute to explain its extinction in the region. Nevertheless, Tsuga might have persisted here for longer time but could have disappeared because of competition with other conifers such as Cedrus, more tolerant to dryness.

Accordingly, it appears that two plant refuge areas were sketched out during the Quaternary at the far North and South of Anatolia, respectively. The coastal Black Sea region today seems to be very impoverished (Quézel and Médail, 2003), maybe because of anthropogenic disturbance (Kaya and Raynal, 2001). Southern Anatolia can be considered as a more propitious refuge area thanks to the occurrence of South-facing mountains that provided elevated humidity in warm valleys.

A review of the extinction history of four very significant taxa representing different bioclimatic plant communities (Avicennia: megathermic taxon; Engelhardia: mega-mesothermic taxon; Taxodiaceae: mega-mesothermic taxa inhabiting swamps; Carya: mesothermic taxon) in Western Europe, North Africa and Near East is given below. The age of their extinctions from these regions during the late Cenozoic is relatively well constrained (Fig. 5).

Avicennia (Verbenaceae) is a mangrove tree that grows today in coastal areas of the intertropical zone. It can be the only representative of mangrove ecosystem in some extra tropical areas (Fig. 5a; Tomlinson, 1986). Because of its relatively big size and entomophilous pollination, this pollen is generally rare in marine coastal sediments and indicates, when it is recorded, proximity to mangrove ecosystem (Thanikaimoni, 1987). According to its last occurrences in pollen records (Fig. 5b), Avicennia disappeared first from the northern Mediterranean coastlines (Jiménez-Moreno, 2005), probably as a result of the middle Miocene marine regression and global climate cooling (Zachos et al., 2001). Then, Avicennia persisted in the south Mediterranean shorelines with an extinction gradient from the West to East. The residual Avicennia mangrove on the North Anatolia coastline (until $4.8 \mathrm{Ma}$, even 1.6 Ma?) must be considered as an actual refuge if compared to its absence at the same time on the southeastern Mediterranean shoreline despite a floristic assemblage rich in megathermic elements (boreholes 
Naf 1 and 2 offshore the Nile Delta and Gan Yavne 5 in Palestine: Drivaliari, 1993; Fauquette et al., 2006) close to its present-day presence along the Red Sea. Some other megathermic plants have been recorded in western Transcaucasia up to the end of the early Pliocene (Shatilova et al., 2011).

Engelhardia (Juglandaceae) is a subtropical tree, common in Southeast Asia (Fig. 5c; AnMing, 1982). Its pollen is frequent to abundant in the European Miocene (Bessedik, 1985; Jiménez-Moreno and Suc, 2007; Jiménez-Moreno et al., 2008). The genus shows an extinction pattern during the Pliocene and early Pleistocene with decreasing ages from Northern to Southern Europe (Fig. 5d), in relation with the Northern Hemisphere temperature evolution (Tiedemann et al., 1994; Popescu et al., 2010). However, Engelhardia survived later in the southern Mediterranean (Fig. 5d) probably because of persisting high temperature but disappeared probably because of increasing dryness (Suc et al., 1995b). Engelhardia persisted up to Middle-Late Pleistocene in two areas, the West Adriatic and North Anatolia coastlines (Fig. 5d), probably milder and more humid areas. The last pollen evidence of Engelhardia in western Transcaucasia is reported in the early Middle Pleistocene (0.6-0.5 Ma; Fig. 5d) by Shatilova et al. (2011).

Two genera of the Taxodiaceae family inhabit subtropical to warm-temperate marine coastal or lacustrine swamps: Taxodium distichum (Northeast America) and Glyptostrobus pensilis (Southeast China) (Fig. 5e; Sternitzke, 1972; Fang et al., 2011). Their pollen is not always distinguished from each other and are usually classified as Taxodiaceae with papilla, leading to some imprecision in reconstructing the history of Taxodiaceae swamps in Europe, mainly constituted by Glyptostrobus if we refer to plant macroremains (Kovar-Eder et al., 2006). In Figure $5 \mathrm{f}$ we show the last record of all the Taxodiaceae pollen grains with papilla. On the whole, the pattern of extinction of these Taxodiaceae from Europe is almost similar to that of Engelhardia but at a younger time, during the earliest Pleistocene climatic cycles (Figs. 5d, 5f). A similar interaction is revealed between decrease in temperature and increase in dryness, opposing the North and South Mediterranean shorelines. Another opposition in humidity is particularly expressed on both edges of the Eastern Pyrenees with about 2 Myrs of delay on the more humid southern slope (Fig. 5f). As previously, two refuge areas of Taxodiaceae swamps are identified for the Middle Pleistocene, the Apeninnes-Adriatic area and the southwestern Black Sea area. Coastal Colchis is a part of the latter refuge area, where Shatilova et al. (2011) place the last record of lowland Taxodiaceae in the older part of the Last Glacial (ca. $50 \mathrm{ka}$; Fig. 5f), according to both pollen and macroremain evidences.

Carya is a warm-temperate genus requiring high humidity, distributed today in two disconnected areas, Northeastern America and Eastern China (Fig. 5g; An-Ming, 1982; Thompson et al., 2000). Its extinction from Europe occurred a little later than that of Taxodiaceae, in relation with the repeated coolings of the Middle Pleistocene, earlier in Northern Europe, forced by decrease in temperature, and Northern Africa, forced by increase in dryness (Fauquette et al., 1998; Klotz et al., 2006; Feddi et al., 2011; Fig. 5h). A refuge area has been identified in southern France up to the Last Glacial (Suc et al., in progress) and it persisted in northern Anatolia until the Holocene (Fig. 5h). Similarly, the last record of Carya pollen in western Transcaucasia is in the early Last Glacial (ca. 50 ka; Shatilova et al., 2011; Fig. 5h), that illustrates the decline of the northern Anatolia refuge area to which it belongs.

\subsection{Evolution of Northern - Southern Anatolia and nearby western Transcaucasia plant refuge areas}

Fossil records suggest that the Colchis (western Transcaucasia) plant refuge area experienced almost the same timing in thermophilous/hygrophilous plant extinctions than the nearby northern Anatolia. They will be grouped in the following synthesis. 


\subsubsection{Changes in the location of thermophilous and hygrophilous plant refuges through time}

Location of plant refuges in Europe and surrounding regions is taking shape as the knowledge progresses on clarifying processes of restriction $v s$. enlargement of their distribution areas and the causes of their extinction (Milne and Abbott, 2002; Svenning, 2003; Leroy, 2007; Leroy and Arpe, 2007).

An inventory of present-day plant refuges within the Mediterranean region has been drawn up by Quézel and Médail (2003). Some relativity of the notion of plant refuge area follows from this study, according to the climatic conditions that the relict taxa withstand. However, our investigation at the scale of the whole Mediterranean region focuses on some emblematic thermophilous and/or hygrophilous trees. Meso-microthermic (Cathaya) and microthermic (Cedrus, Tsuga) trees will be dealt in forthcoming syntheses.

Lower-middle Miocene pollen records from Anatolia (Fig. 2) do not show significant differences with coeval pollen floras from Western Europe. Accordingly, Anatolia cannot be considered as a plant refuge area before the early Pliocene. The onset of the status of Anatolia as a thermophilous and/or hygrophilous plant refuge area may result from increasing monsoon influence (and associated summer rainfall) over the northeastern Mediterranean region (Popescu et al., 2006). At the early Pliocene, Anatolia was already split into two plant refuge areas, on its North and South coastlines, respectively. This disjunction is signalled by the oldest evidence of development of Artemisia steppe in the Tortonian deposits from Akdağ and Bayramhacilı (Yavuz-Işik and Toprak, 2010), probably resulting from the uplift of the Central Anatolian Plateau which started at $c a .8 \mathrm{Ma}$ in its southern margin (Cosentino et al., 2012). The northward development of the Anatolian Artemisia steppe is then recorded at ca. $5.7 \mathrm{Ma}$ at Site 380 (Popescu, 2006). Based on a vegetation numerical models with some control by palaeofloras, the presence of humid areas, which may have protected thermophilous and/or hygrophilous trees both on the northern and southern coastlines of Anatolia is indicated by François et al. (2011) for the late Miocene and Arpe et al. (2011) for the Last Glacial Maximum.

A comparative reconstruction of plant refuge areas at a Eurasian scale is attempted in Figure 6 for some selected taxa or groups of taxa at different time slices until Present. During the early Pliocene, northern Anatolia and western Transcaucasia appear to have been refuge areas for megathermic plants as well as Sicily, northern Africa and southern Iberia (Fig. 6a). The nearest present refuge areas are located in the Canary Islands and along the Red Sea shoreline, which is the nearest area to be inhabited by Avicennia (Fig. 6a).

The Central Mediterranean (from Tunisia to cental Adriatic Sea) and northern Anatolia must be regarded as early Pleistocene refuge areas for Taxodiaceae (mostly inhabiting coastal swamps), which persisted up to the Holocene in the latter (Fig. 6b). Many researchers have questioned the long-time survival of Taxodiaceae in this region as its pollen has often been considered as "mostly, if not entirely, reworked" in Caspian Holocene and Pleistocene sediments (Richards et al., 2011), although this opinion has been recently moderated in admitting possible relict populations (Richards et al., 2014). The age of disappearance of Taxodiaceae in this region was indeed considered as unknown, until the record of their decline and extinction in Site 380 (Fig. 3). And yet occurrence of Taxodiaceae in the residual Paratethys (southern Black Sea) until the early Last Glacial is supported by pollen and macrofloral records from western Transcaucasia (Shatilova et al., 2011; Fig. 6b). A highly fragmented Taxodiaceae distribution from the Near East to China is hence suggested for the late Quaternary.

During the Holsteinian (Late Pleistocene: $c a .0 .4 \mathrm{Ma}$ ), several of the emblematic mesothermic and/or hygrophilous trees Carya, Pterocarya, Zelkova, Liquidambar and Parrotia persica invaded a very large territory in Europe (Bińka et al., 2003; Kondratienė and Šeirienė, 2003; Gerasimenko, 2008; Koutsodendris et al., 2010), greatly beyond their present-day residual biotopes scattered in the Central Mediterranean and Middle East (Fig. 6c). 
These significant examples suggest that the evolution of refuge areas of thermophilous and/or hygrophilous plants must be understood as successive restrictions and fragmentations of former populations. The status of a geographic region as plant refuge area must only be considered as a shot at a given time, being highly evolutive with respect to fragility of ecosystems submitted to climatic changes, possibly diseases in fragmented areas and more recently by human disturbance (Willis and Niklas, 2004; Leroy, 2007; Leroy and Arpe, 2007).

\subsubsection{Causes of evolution of thermophilous-hygrophilous plant refuges}

There are several more or less connected causes of the retreat and disjunction of geographic areas occupied by thermophilous and/or hygrophilous plants:

- the long-term physiographic evolution of the Mediterranean and surrounding regions characterized by the onset of West-East barriers restraining even preventing the NorthSouth migrations of plants in relation with temperature and humidity fluctuations (mountains: Pyrenees, Alps, Apennines, Hellenids, Carpathians, Taurids, Caucasus; Mediterranean Sea and reducing-scattering Paratethys; semi-deserts and deserts: Central Iberia, Anatolian Plateau, Sahara, Arabia) (Suc et al., 1995a). This is very different than in North America, where similar natural barriers are rather North-South oriented;

- the climatic changes, characterized by repeated more and more severe coolings and arid periods and less intense warmings that developed since 5.08 Ma (Combourieu-Nebout, 1990; Suc et al., 1995a; Suc and Popescu, 2005; Leroy, 2007; Joannin et al., 2008, 2011; Bertini et al., 2010; Popescu et al., 2010; Suc et al., 2010) causing also the growth of dry plant ecosystems;

- the onset of a Mediterranean seasonality, producing the extinction of hygrophilous species not adapted to a dry season (Suc, 1984);

- probably the increased frailty of plants suffering unfavourable conditions in the refuge places;

- at last, human activities, leading to extinction of greatly weakened residual communities of thermophilous and/or hygrophilous trees.

With $17.3^{\circ} \mathrm{C}$ as mean annual temperature, $7^{\circ} \mathrm{C}$ as mean temperature of the coldest month, $25.5^{\circ} \mathrm{C}$ as mean temperature of the warmest month, $1100 \mathrm{~mm}$ as annual precipitation (Fauquette et al., 2006), the reconstructed climatic conditions for Site 380 at the earliest Pliocene were less convenient than the present-day climatic conditions in which Glyptostrobus pensilis occurs (Fang et al., 2011). In addition to uncertainty on palaeoclimate reconstructions, it is possible that the Glyptostrobus fossil species (G. europaeus according to palaeobotanists; Kasapligil, 1977; Velitzelos and Gregor, 1990; Gemici et al., 1991; İ nci, 2002), which probably lived in the Mediterranean region, was less demanding in terms of temperature and precipitation than the modern G. pensilis if comparing its life conditions (Fang et al., 2011) and Zanclean reconstructions by Fauquette et al. (1998) in the Northwestern Mediterranean. Global coupled simulations indicate a decrease of the mean annual temperature of $3-4^{\circ} \mathrm{C}$ in Anatolia during the Last Glacial Maximum (Kim et al., 2008; Schmittner et al., 2011) with a low increase in meridional heat flux and a slight lowering in summer rainfall, both with respect to Present (Kim et al., 2008). Arpe et al. (2011) obtained mean temperatures that are comprised between -0.1 and $-5^{\circ} \mathrm{C}$ for winter and 10 and $20^{\circ} \mathrm{C}$ for summer for the same period (T106EH5 simulations). Such optimal glacial conditions could have allowed persistence of small and isolated populations of Glyptostrobus along the south Black Sea shoreline. Now, protected swampy Taxodiaceae individuals are usually cultivated in European private and botanical gardens up to high latitudes. A significant example of acclimatization is observed around the Nantua Lake in the Jura Massif (46 ${ }^{\circ}$ ' $19^{\prime \prime} \mathrm{N}, 5^{\circ} 35^{\prime} 59^{\prime \prime} \mathrm{E}$, altitude $475 \mathrm{~m}$ ) where they have been introduced in the late eighties. The trees flourish and reproduced into several distant colonies under relatively low temperature 
but humid conditions: $10.3^{\circ} \mathrm{C}$ as mean annual temperature, $1{ }^{\circ} \mathrm{C}$ as mean temperature of the coldest month, $20^{\circ} \mathrm{C}$ as mean temperature of the warmest month, $1700 \mathrm{~mm}$ as annual precipitation (Auffray et al., 2011). Adaptation of specimens of swampy Taxodiaceae to such hard climatic conditions suggests that Glyptostrobus could have survived on the south Black Sea shore during past glacials. In addition, the Anatolian Glyptostrobus survival might have benefited from some reinforcement of the monsoon during glacials (Masson et al., 2000; Wang et al., 2008). This proposed history is not contradicted by modeling performed by Arpe et al. (2011), who simulated two refuge areas of thermophilous trees during the Last Glacial Maximum, to the north and south of the eastern Anatolia (Fig. 1b), respectively. Extinction of Taxodiaceae can be regarded as being caused by human activities, as Glyptostrobus pensilis today suffers in China and Vietnam.

Examination of the present dispersal of ecosystems with Pterocarya fraxinifolia, Zelkova $(Z$. abelicea, Z. crenata, Z. sicula), Liquidambar orientalis and Parrotia persica in the Central and Eastern Mediterranean region and Middle East leads us to foresee their forthcoming reexpansion in Europe within the frame of the warming in progress, maybe through some reintroduction processes in order to counterbalance the expected increase in dryness over the Mediterranean region (Giorgi and Lionello, 2008; Somot et al., 2008).

\section{Conclusions}

The long continuous pollen record from Site 380, completed by several discontinuous Miocene pollen floras, provides a unique opportunity to synthesize the pattern of plant extinctions along the last $6 \mathrm{Ma}$ in the Anatolian region known by its plant refuges.

Anatolia must be considered as a refuge area for thermophilous-hygrophilous plants since the early Pliocene (at about $5 \mathrm{Ma}$ ), scattered in two territories, on its northern and southern coastlines. The onset of this status of thermophilous-hygrophilous plant refuge appears as a consequence of both reinforcement of East Africa monsoon and retreat of the epicontinental Paratethys Sea.

Contraction and division of thermophilous-hygrophilous plant refuges in Europe and around the Mediterranean region in the past $5 \mathrm{Ma}$ is a consequence of physiographic evolution (mountain uplift), climatic changes (repeated severe coolings and aridifications), introduction of Mediterranean seasonality and more recently human activities.

The most striking example is provided by the swampy Taxodiaceae genus Glyptostrobus, which might have persisted along the southern Black Sea shore until recently.

Cedrus is documented to be a continuous component of the Anatolian flora since at least 23 Ma.

The present thermophilous-hygrophilous relictual trees in Anatolia, Pterocarya fraxinifolia, Zelkova abelica and Liquidambar orientalis, could benefit from the present climate warming for some re-expansion in Europe.

\section{Acknowledgements}

D. Biltekin was funded by $\mathrm{PhD}$ grants (ITU-EMCOL grant, Turkey - French Ministry of Research). Samples from Site 380 were provided by ODP, samples from Ermenek by C. Messina and the late D. Joly, those from Avadan and Karyayla by G. Kelling. We particularly appreciate the comments from S.A.G. Leroy and from an anonymous reviewer, who significantly helped us to improve the manuscript. D. Ivanov and M. Philippe are thanked for the information on the Satovcha pollen flora, and on the present-day Taxodiaceae from the Nantua Lake, respectively. This paper is a contribution to the French ANR EGEO Project (ANR-06-BLAN-0156 CSD 6). 


\section{References}

Akgün, F., Akyol, E., 1999. Palynostratigraphy of the coal-bearing Neogene deposits graben in Büyük Menderes Western Anatolia. Geobios 32, 3, 367-383.

Akman, Y., Quézel, P., Ketenoglu, O., Kurt, F., 1993. Analyse syntaxonomique des forêts de Liquidambar orientalis en Turquie. Ecologia Mediterranea 19, 49-57.

Albianelli, A., Bertini, A., Magi, M., Napoleone, G., Sagri, M., 1995. Il bacino plio-pleistocenico del Valdarno superiore: eventi deposizionali, paleomagnetici e paleoclimatici. Il Quaternario 8, 1, 11-18.

Amigues, S., 2007. Le styrax et ses usages antiques. Journal des Savants 2, 263-318.

An-Ming, L., 1982. On the geographical distribution of the Juglandaceae. Acta Phytotaxonomica Sinica 20, 3, 257-274 (in Chinese).

Anşin, R., Küçük, M., 1990. Niksar ve Erbaa yöreleri doğal sedir meşcerelerinde floristic araştırmalar. Ormancılık Araştırma Enstitüsü Muhtelif Yayınlar 59, 1-11.

Armijo, R., Meyer, B., Hubert, A., Barka, A., 1999. Westward propagation of the North Anatolian fault into the northern Aegean: timing and kinematics. Geology 27, 267-270.

Arpe, K., Leroy, S.A.G., Mikolajewicz, U., 2011. A comparison of climate simulations for the last glacial maximum with three different versions of the ECHAM model and implications for summer-green tree refugia. Climate of the Past 7, 91-114.

Aubréville, A., 1974. Origines polytopiques des Angiospermes tropicales (2ème partie). Adansonia ser. 2, 14, 2, 145-198.

Auffray, A., Brisson, A., Tamburini, A., Dziak, V., Maloisel, V., Martinoni-Lapierre, S., 2011. Climat de la région Rhône-Alpes. Météo-France Centre-Est, Division DéveloppementsEtudes-Climatologie, $47 \mathrm{pp}$ (http://srcae.rhonealpes.fr/static/cms_page_media/24/rapportclimat-final.pdf).

Aytuğ, B., 1961. Etude des pollens du genre Cèdre (Cedrus Link.). Pollen et Spores 3, 1, 47-54.

Bachiri Taoufiq, N., 2000. Les environnements marins et continentaux du corridor rifain au Miocène supérieur d'après la palynologie. Unpublished PhD Thesis, University Hassan IIMohammedia, Casablanca, 212 pp.

Bachiri Taoufiq, N., Barhoun, N., Suc, J.-P., Méon H., Elaouad, Z., Benbouziane, A., 2000. Environnement, végétation et climat du Messinien au Maroc. Paleontologia i Evolució 3233, 127-145.

Beaudouin, C., Jouet, G., Suc, J.-P., Berné, S., Escarguel, G., 2007. Vegetation dynamics in southern France during the last $30 \mathrm{ky}$ BP in the light of marine palynology. Quaternary Science Reviews 26, 1037-1054.

Benda, L., 1971. Grundzüge einer pollenanalytischen Gliederung des Türkischen Jungtertiärs. Beihefte zum Geologischen Jahrbuch 113, 1-45.

Bertini, A., 2001. Pliocene climatic cycles and altitudinal forest development from $2.7 \mathrm{Ma}$ in the Northern Apennines (Italy): evidence from the pollen record of the Stirone section (5.1 to 2.2 Ma). Geobios 34, 253-265.

Bertini, A., Ciaranfi, N., Marino, M., Palombo, M.R., 2010. Proposal for Pliocene and Pleistocene land-sea correlation in the Italian area. Quaternary International 219, 95-108.

Bessedik, M., 1985. Reconstitution des environnements miocènes des régions nord-ouest méditerranéennes à partir de la palynologie. Unpublished $\mathrm{PhD}$ Thesis, University of Montpellier 2, $162 \mathrm{pp}$.

Besson, D., Parize, O., Rubino, J.-L., Aguilar, J.-P., Aubry, M.-P., Beaudoin, B., Berggren, W.A., Clauzon, G., Crumeyrolle, P., Dexcoté, Y., Fiet, N., Iaccarino, S., Jiménez-Moreno, G., Laporte-Galaa, C., Michaux, J., von Salis, K., Suc, J.-P., Reynaud, J.-Y., Wernli, R., 
2005. Un réseau fluviatile d'âge burdigalien terminal dans le sud-est de la France: remplissage, extension, âge, implications. Comptes-Rendus Geoscience, Stratigraphie, Géomorphologie 337, 1045-1054.

Biltekin, D., 2010. Vegetation and climate of North Anatolian and North Aegean region since 7 $\mathrm{Ma}$ according to pollen analysis. Unpublished $\mathrm{PhD}$ Thesis, Istanbul Technical University and University Claude Bernard-Lyon 1, 136 pp.

Bińka, K., Nitychoruk, J., Dzierżek, J., 2003. Parrotia persica C.A.M. (Persian witch hazel, Persian ironwood) in the Mazovian (Holsteinian) Interglacial of Poland. Grana 42, 227233.

Boydak, M., Çalikoğlu, M., 2008. Biology and silviculture of the Lebanon Cedar (Cedrus libani A. Rich.). Ogem-Vak, Ankara, 228 pp.

Brush, G.S., DeFries, R.S., 1981. Spatial distribution of pollen in surface sediments of the Potomac Estuary. Limnology and Oceanography 26, 2, 295-309.

Buisine, C., 2000. Analyse palynologique dans un contexte géodynamique actif: application aux coupes plio-pléistocènes de Kolimpia et de Tsampika (Rhodes, Grèce). Unpublished Master Thesis, University Claude Bernard-Lyon 1, 24 pp.

Clet-Pellerin, M., 1983. Le Plio-Pléistocène en Normandie. Apports de la palynologie. Unpublished $\mathrm{PhD}$ Thesis, University of Caen, $135 \mathrm{pp}$.

Clet-Pellerin, M., Lautridou, J.-P., Morzadec-Kerfourn, M.-T., Farjanel, G., Huault, M.-F., 1999. Stratigraphy and palynology of the Late Pliocene and Early Pleistocene: Sequences in marine and lagunal sediments in Normandy (France). In: Wrenn, J.H., Suc, J.-P., Leroy, S.A.G. (Eds.), The Pliocene: Time of Change. American Association of Stratigraphic Palynologists Foundation, Dallas, pp. 131-143.

Clet-Pellerin, M., Le Calvez, Y., Pareyn, C., 1985. Le Tiglien dans le Cotentin. Essai de datation par les pollens et les Foraminifères d'un forage effectué au Bosq d'Aubigny (Manche). Sciences Géologiques 38, 67-71.

Combourieu-Nebout, N., 1990. Les cycles glaciaire-interglaciaire en region méditerranéenne de 2,4 à -1,1 Ma: Analyse pollinique de la série de Crotone (Italie méridionale). Paléobiologie continentale 17, 35-59.

Cornée, J.-J., Moissette, P., Joannin, S., Suc, J.-P., Quillevéré, F., Krijgsman, W., Hilgen, F., Koskeridou, E., Lécuyer, C., Desvignes, P., 2006. Tectonic and climatic controls on coastal sedimentation: the Late Pliocene-Middle Pleistocene of northeastern Rhodes, Greece. Sedimentary Geology 187, 159-181.

Cosentino, D., Schildgen, T.F., Cipollari, P., Faranda, C., Gliozzi, E., Hudáčková, N., Lucifora, S., Strecker, M., 2012. Late Miocene surface uplift of the southern margin of the central Anatolian Plateau, Central Taurides, Turkey. Geological Society of America Bulletin, 124, $1-2,133-145$.

Cravatte, J., Suc, J.-P., 1981. Climatic evolution of North-Western Mediterranean area during Pliocene and Early Pleistocene by pollen-analysis and forams of drill Autan 1. Chronostratigraphic correlations. Pollen et Spores, 23, 2, 247-258.

Denèfle, M., Lézine, A.-M., Fouache, E., Dufaure, J.-J., 2000. A 12,000-Year Pollen Record from lake Maliq, Albania. Quaternary Research, 54, 423-432.

Denk, Th. 1998. The beech (Fagus L.) in western Eurasia - an actualistic approach. Feddes Repertorium 109(5-6), 435-463.

Denk, Th., Frotzler, N., Davitashvili, N., 2001. Vegetational patterns and distribution of relict taxa in humid temperate forests and wetlands of Georgia (Transcaucasia). Biological Journal of the Linnean Society 72, 287-332.

Diniz, F., 1984. Apports de la palynologie à la connaissance du Pliocène portugais. Rio Maior: un bassin de référence pour l'histoire de la flore, de la végétation et du climat de la façade 
atlantique de l'Europe méridionale. Unpublished PhD Thesis, University of Montpellier 2, $230 \mathrm{pp}$.

Di Pasquale, G. Garfi, G., Quézel, P., 1992. Sur la présence d'un Zelkova nouveau en Sicile sudorientale (Ulmaceae). Biocosme mésogéen 8-9, 401-409.

Doláková, N., Burešová, A., 2007. Use of fluorescent microscopy in the study of redeposited palynomorphs in the cave and marine sediments of Moravia (Czech Republic). Acta Palaeobotanica 47, 1, 275-279.

Drivaliari, A., 1993. Images polliniques et paléoenvironnements au Néogène supérieur en Méditerranée orientale. Aspects climatiques et paléogéographiques d'un transect latitudinal (de la Roumanie au Delta du Nil). Unpublished PhD Thesis, University of Montpellier 2, $333 \mathrm{pp}$.

Dubois, J.-M., 2001. Cycles climatiques et paramètres orbitaux vers 1 Ma. Etude de la coupe de Monte San Giorgio (Caltagirone, Sicile): palynologie, isotopes stables, calcimétrie. Unpublished Master Thesis, University of Lyon 1, $52 \mathrm{pp}$.

Erdtman, G., 1965. Pollen and spore morphology/Plant taxonomy. Gymnospermae, Bryophyta. Almqvist and Wiksell, Stockholm, $191 \mathrm{pp}$.

Fang, J., Wang, Z., Tang, Z. (Eds.), 2011. Atlas of Woody Plants in China. Distribution and Climate, Vol. 2, Springer, 1902 pp.

Farjanel, G., 1985. La flore et le climat du Néogène et du Pléistocène de Bresse (France) d'après l'analyse pollinique. Implications chronostratigraphiques. Documents du Bureau de Recherches Géologiques et Minières 97, 1-202.

Fauquette, S., Guiot, J., Suc, J.-P., 1998. A method for climatic reconstruction of the Mediterranean Pliocene using pollen data. Palaeogeography, Palaeoclimatology, Palaeoecology 144, 183-201.

Fauquette, S., Suc, J.-P., Bertini, A., Popescu, S.-M., Warny, S., Bachiri Taoufiq, N., Perez Villa, M.-J., Chikhi, H., Subally, D., Feddi, N., Clauzon, G., Ferrier, J., 2006. How much did climate force the Messinian salinity crisis? Quantified climatic conditions from pollen records in the Mediterranean region. Palaeogeography, Palaeoclimatology, Palaeoecology $238,1-4,281-301$.

Fauquette, S., Suc, J.-P., Jiménez-Moreno, G., Micheels, A., Jost, A., Favre, E., Bachiri-Taoufiq, N., Bertini, A., Clet-Pellerin, M., Diniz, F., Farjanel, G., Feddi, N., Zheng, Z., 2007. Latitudinal climatic gradients in Western European and Mediterranean regions from the Mid-Miocene (c. $15 \mathrm{Ma}$ ) to the Mid-Pliocene (c. $3.5 \mathrm{Ma}$ ) as quantified from pollen data. In: Williams, M., Haywood, A., Gregory, J., Schmidt, D.N. (Eds.), Deep-Time Perspectives on Climate Change. Marrying the Signal from Computer Models and Biological Proxies. The Micropaleontological Society, The Geological Society, London Special Publications, pp. 481-502.

Feddi, N., Fauquette, S., Suc, J.-P., 2011. Histoire plio-pléistocène des écosystèmes végétaux de Méditerranée sud-occidentale : apport de l'analyse pollinique de deux sondages en mer d'Alboran. Geobios 44, 57-69.

Follieri, M., 2010. Conifer extinction in Quaternary Italian records. Quaternary International 225, 37-43.

Follieri, M., Magri, D., Sadori, L., 1986. Late Pleistocene Zelkova extinction in Central Italy. New Phytologist 103, 269-273.

Fouache, E., Dalongeville, R., Kunesch, S., Suc, J.-P., Subally, D., Prieur, A., Lozouet, P., 2005. The Environmental Setting of the Harbor of the Classical Site of Oeniades on the Acheloos Delta, Greece. Geoarchaeology: An International Journal 20, 3, 285-302.

Fourniguet, J., Trautmann, F., Margerel, J.-P., Whatley, R.C., Maybury, C., Morzadec-Kerfourn, M.-T., 1989. Les argiles et sables pliocènes de Saint-Jean-la-Poterie (Morbihan): 
Sédimentologie, micropaleontologie (foraminifères, ostracodes et palynologie). Géologie de la France 1-2, 55-78.

François, L., Utescher, T., Favre, E., Henrot, A.-J., Warnant, P., Micheels, A., Erdei, B., Suc, J.P., Cheddadi, R., Mosbrugger, V., 2011. Modelling Late Miocene vegetation in Europe: Results of the CARAIB model and comparison with palaeovegetation data. Palaeogeography, Palaeoclimatology, Palaeoecology 304, 359-378.

Gemici, Y., Akyol, E., Akgün, F., Seçmen, Ö., 1991. Soma kömür havzası fosil makro ve mikrofloras1. Maden Tetkik ve Arama Dergisi 11, 161-178.

Geraga, M., Tsaila-Monopolis, S., Ioakim, C., Papatheodorou, G., Ferentinos, G., 2005. Shortterm climate changes in the southern Aegean Sea over the las 48,000 years. Palaeogeography, Palaeoclimatology, Palaeoecology 220, 311-332.

Gerasimenko, N., 2008. Pleistocene environmental evolution of the Ukrainian Carpathians, based on palynology. 33rd International Geological Congress, Oslo, session HPF-12, abstract.

Gibbard, P.L., West, R.G., Zagwijn, W.H., Balson, P.S., Burger, A.W., Funnell, B.M., Jeffrey, D.H., de Jong, J., van Kolfschoten, T., Lister, A.M., Meijer, T., Norton, P.E.P., Preece, R.C., Rose, J., Stuart, A.J., Whiteman, C.A., Zalasiewicz, J.A., 1991. Early and Early Middle Pleistocene correlations in the Southern North Sea Basin. Quaternary Science Reviews 10, 23-52.

Giorgi, F., Lionello, P., 2008. Climate change projections for the Mediterranean region. Global and Planetary Change 63, 90-104.

Havinga, A.J., 1967. Palynology and pollen preservation. Review of Palaeobotany and Palynology 2, 81-98.

Heissig, K., 1976. Rhinocerotidae (Mammalia) aus der Anchitherium-Fauna Anatoliens. Geologisches Jahrbuch Reihe B, 19, 121 pp.

Ilgar, A., Nemec, W., 2005. Early Miocene lacustrine deposits and sequence stratigraphy of the Ermenek Basin, Central Taurides, Turkey. Sedimentary Geology 173, 233-275.

İnci, U., 2002. Depositional evolution of Miocene coal successions in the Soma coalfield, western Turkey. International Journal of Coal Geology 51, 1-29.

Ioakim, C., 1984. Analyse palynologique des dépôts lacustres du Pliocène de Prolemais (Grèce septentrionale): un élément nouveau dans la reconstitution de l'histoire paléoclimatique des régions méditerranéennes orientales. Paléobiologie continentale 14, 2, 315-332.

Ioakim, C., Koutsouveli, A., Tsaila-Monopolis, S., Theodossiou, I., 1997. Palaeoenvironmental and palaeoclimatic conditions during the upper Miocene - lower Pliocene in the Sitia region (Eastern Crete, Greece). Revue de Paléobiologie 16, 1, 187-195.

Ioakim, C., Rondoyani, T., 1988. Contribution à l'étude géologique de la région de Zeli, Locride (Grèce centrale). Revue de Micropaléontologie 31, 2, 129-136.

Ioakim, C., Solounias, N., 1985. A radiometrically dated pollen flora from the Upper Miocene of Samos Island, Greece. Revue de Micropaléontologie 28, 3, 197-204.

İslamoğlu, Y., Harzhauser, M., Gross, M., Jiménez-Moreno, G., Coric, S., Kroh, A., Rögl, F., van der Made, J., 2010. From Tethys to eastern Paratethys: Oligocene depositional environments, paleoecology and paleobiogeography of the Thrace Basin (NW Turkey). International Journal of Earth Sciences 99, 183-200.

Ivanov, D., 2003. Palynological data on the Miocene flora and vegetation of the Sandanski Graben. Phytologia Balcanica 9, 2, 197-206.

Ivanov, D.A., Ashraf, A.R., Mosbrugger, V., 2007. Late Oligocene and Miocene climate and vegetation in the Eastern Paratethys area (northeast Bulgaria), based on pollen data. Palaeogeography, Palaeoclimatology, Palaeoecology 255, 342-360. 
Jiménez-Moreno, G., 2005. Utilización del análisis polínico para la reconstrucción de la vegetación, clima y paleoaltitudes a lo largo del arco alpino europeo durante el Mioceno (21-8 Ma). Unpublished PhD Thesis, Universities of Granada and Lyon 1, $312 \mathrm{pp}$.

Jiménez-Moreno, G., Fauquette, S., Suc, J.-P., 2008. Vegetation, climate and palaeoaltitude reconstructions of the Eastern Alps during the Miocene based on pollen records from Austria, Central Europe. Journal of Biogeography 35, 1638-1649.

Jiménez-Moreno, G., Fauquette, S., Suc, J.-P., 2010. Miocene to Pliocene vegetation reconstruction and climate estimates in the Iberian Peninsula from pollen data. Review of Palaeobotany and Palynology 162, 403-415.

Jiménez-Moreno, G., Popescu, S.-M., Ivanov, D., Suc, J.-P., 2007. Neogene flora, vegetation and climate dynamics in Central Eastern Europe according to pollen records. In: Williams, M., Haywood, A., Gregory, J., Schmidt, D.N. (Eds.), Deep-Time Perspectives on Climate Change. Marrying the Signal from Computer Models and Biological Proxies. The Micropaleontological Society, The Geological Society, London Special Publications, pp. 393-406.

Jiménez-Moreno, G., Suc, J.-P., 2007. Middle Miocene latitudinal climatic gradient in Western Europe: Evidence from pollen records. Palaeogeography, Palaeoclimatology, Palaeoecology 253, 224-241.

Jinxing, L., Yuxi, H., 2000. Atlas of structure of Gymnosperms. Science Press, Beijing, 244 pp.

Joannin, S., Bassinot, F., Combourieu Nebout, N., Peyron, O., Beaudouin, C., 2011. Vegetation response to obliquity and precession forcing during the Mid-Pleistocene transition in Western Mediterranean region (ODP site 976). Quaternary Science Reviews 30, 280-297.

Joannin, S., Ciaranfi, N., Stefanelli, S., 2008. Vegetation changes during the late Early Pleistocene at Montalbano Jonico (Province of Matera, southern Italy) based on pollen analysis. Palaeogeography, Palaeoclimatology, Palaeoecology 270, 92-101.

Joannin, S., Cornée, J.-J., Moissette, P., Suc, J.-P., Koskeridou, E., Lécuyer, C., Buisine, C., Kouli, K., Ferry, S., 2007. Changes in vegetation and marine environments in the eastern Mediterranean (Rhodes, Greece) during the Early and Middle Pleistocene. Journal of the Geological Society of London 164, 1119-1131.

Julià Bruguès, R., Suc, J.-P., 1980. Analyse pollinique des dépôts lacustres du Pléistocène inférieur de Banyoles (Bañolas, site de la Bòbila Ordis - Espagne): un élément nouveau dans la reconstitution de l'histoire paléoclimatique des régions méditerranéennes d'Europe occidentale. Geobios 3, 1, 5-19.

Kayseri-Özer, M.S., 2014. Spatial distribution of climatic conditions from the Middle Eocene to Late Miocene based on palynoflora in Central, eastern and Western Anatolia. Geodynamica Acta 26(1-2), doi: 10.1080/09853111.2013.877237.

Karistineos, N., Ioakim, C., 1989. Palaeoenvironmental and palaeoclimatic evolution of the Serres Basin (N. Greece) during the Miocene. Palaeogeography, Palaeoclimatology, Palaeoecology 70, 275-285.

Kasaplıgil, B., 1977. A Late-Tertiary conifer-hardwood forest from the vicinity of Güvem village, near Kizılcahamam, Ankara. Bulletin of the Mineral Research and Exploration Institute of Turkey 88, 25-33.

Kaya, Z., Raynal, D.J., 2001. Biodiversity and conservation of Turkish forests. Biological Conservation 97, 131-141.

Kim, S.-J., Crowley, T.J., Erickson, D.J., Govindasamy, B., Duffy, P.B., Lee, B.Y., 2008. Highresolution climate simulation of the last glacial maximum. Climate Dynamics 31, 1-16.

Kloosterboer-van Hoeve, M., 2000. Cyclic changes in the late Neogene vegetation of northern Greece. Laboratory of Palaeobotany and Palynology Contribution Series 12, 9-131. 
Klotz, S., Fauquette, S., Combourieu-Nebout, N., Uhl, D., Suc, J.-P., Mosbrugger, V., 2006. Seasonality intensification and long-term winter cooling as a part of the Late Pliocene climate development. Earth and Planetary Science Letters 241, 174-187.

Kondratiené, O., Šeirienè, V., 2003. Vegetation and climate of the Butenai Interglacial (Holsteinian) in Lithuania. Geological Quarterly 47, 2, 139-148.

Koutsodendris, A., Müller, U.C., Pross, J., Brauer, A., Kotthoff, U., 2010. Vegetation dynamics and climate variability during the Holsteinian interglacial based on a pollen record from Dethlingen (northern Germany). Quaternary Science Reviews 29, 3298-3307.

Kovar-Eder, J., Kvaček, Z., Martinetto, E., Roiron, P., 2006. Late Miocene to Early Pliocene vegetation of southern Europe (7-4 Ma) as reflected in the megafossil plant record. Palaeogeography, Palaeoclimatology, Palaeoecology 238, 321-339.

Kuprianova, L.A., 1965. The Palynology of the Amentiferae (in Russian). The Academy of Sciences of the USSR, The Komarov Botanical Institute, Moscow - Leningrad, 213 pp.

Lericolais, G., Bourget, J., Popescu, I., Jermannaud, P., Mulder, T., Jorry, S., Panin, N., 2013. Late Quaternary deep-sea sedimentation in the western Black Sea: New insights from recent coring and seismic data in the deep basin. Global and Planetary Change 103, 232247.

Lericolais, G., Bulois, C., Gillet, H., Guichard, F., 2009. High frequency sea level fluctuations recorded in the Black Sea since the LGM. Global and Planetary Change 66, 65-75.

Leroy, S.A.G., 2007. Progress in palynology of the Gelasian-Calabrian Stages in Europe: Ten messages. Revue de Micropaléontologie 50, 293-308.

Leroy, S.A.G., 2008. Vegetation cycles in a disturbed sequence around the Cobb-Mountain subchron in Catalonia. Journal of Paleolimnology 40, 3, 851-868.

Leroy, S.A.G., Arpe, K., 2007. Glacial refugia for summer-green trees in Europe and south-west Asia as proposed by ECHAM3 time-slice atmospheric model simulations. Journal of Biogeography 34, 2115-2128.

Leroy, S.A.G., Boyraz, S., Gürbüz, A., 2009. High-resolution palynological analysis in Lake Sapanca as a tool to detect recent earthquakes on the North Anatolian Fault. Quaternary Science Reviews 28, 2616-2632.

Leroy, S.A.G., Kakroodi, A.A., Kroonenberg, S., Lahijani H.K., Alimohammadian H., Nigarov A., 2013. Holocene vegetation history and sea level changes in the SE corner of the Caspian Sea: relevance to SW Asia climate. Quaternary Science Reviews 70, 28-47.

Leroy, S.A.G., Lahijani, H.A.K., Djamali, M., Naqinezhad, A., Moghadam, M.V., Arpe, K., Shah-Hosseini, M., Hosseindoust, M., Miller, Ch.S., Tavakoli, V., Habibi, P., Naderi Beni, M., 2011. Late Little Ice Age palaeoenvironmental records from the Anzali and Amirkola Lagoons (south Caspian Sea): Vegetation and sea level changes. Palaeogeography, Palaeoclimatology, Palaeoecology 302, 415-434.

Leroy, S.A.G., Schwab, M.J., Costa, P.J.M., 2010. Seismic influence on the last 1500-year infill history of Lake Sapanca (North Anatolian Fault, NW Turkey). Tectonophysics 486, 15-27.

Lourens, L.J., Hilgen, F.J., Laskar, J., Shackleton, N.J., Wilson, D., 2005. The Neogene period. In: Gradstein, F.M., Ogg, J.G., Smith, A.G. (Eds.), A Geological Time Scale 2004. Cambridge University Press, Cambridge, pp. 409-440.

Magri, D., 2010. Persistence of tree taxa in Europe and Quaternary climate changes. Quaternary International 219, 145-151.

Magri, D., Parra, I., 2002. Late Quaternary western Mediterranean pollen records and African winds. Earth and Planetary Science Letters 200, 401-408.

Masson, V., Braconnot, P., Jouzel, J., de Noblet, N., Cheddadi, R., Marchal, O., 2000. Simulation of intense monsoons under glacial conditions. Geophysical Research Letters $27,12,1747-1750$. 
Médail, F., Diadema, K., 2009. Glacial refugia influence plant diversity patterns in the Mediterranean Basin. Journal of Biogeography 36, 1333-1345.

Melinte-Dobrinescu, M.C., Suc, J.-P., Clauzon, G., Popescu, S.-M., Armijo, R., Meyer, B., Biltekin, D., Çağatay, M.N., Ucarkus, G., Jouannic, G., Fauquette, S., Çakir, Z., 2009. The Messinian Salinity Crisis in the Dardanelles region: Chronostratigraphic constraints. Palaeogeography, Palaeoclimatology, Palaeoecology 278, 24-39.

Menke, B., 1975. Vegetationsgeschichte und Florenstratigraphie Nordwestdeutschlands im Pliozän und Frühquartär. Mit einem Beitrag zur Biostratigraphie des Weichselfrühglazials. Geologisches Jahrbuch A, 26, 3-151.

Milne, R.I., Abbott, R.J., 2002. The Origin and Evolution of Tertiary Relict Floras. Advances in Botanical Research 38, 281-314.

Mriqo, Z., 2010. La végétation et le climat du Golfe d'Hammamet (Tunisie) du Miocène terminal au Pliocène supérieur d'après l'analyse pollinique. Unpublished Master Thesis, University Hassan II-Mohammedia, Casablanca, 71 pp.

Mudie, P.J., Rochon, A., Aksu, A.E., 2002. Pollen stratigraphy of Late Quaternary cores from Marmara Sea: land-sea correlation and paleoclimatic history. Marine Geology 190, 233260.

Nakoman, E., 1967. Microflore des dépôts tertiaires du sud-ouest de l'Anatolie. Pollen et Spores 9, 1, 121-142.

Naud, G., Suc, J.-P., 1975. Contribution à l'étude paléofloristique des Coirons (Ardèche): premières analyses polliniques dans les alluvions sous-basaltiques et interbasaltiques de Mirabel (Miocène supérieur). Bulletin de la Société Géologique de France 5, ser. 7, 820827.

Nazik, A., 2004. Planktonic foraminiferal biostratigraphy of the Neogene sequence in the Adana Basin, Turkey, and its correlation with standard biozones. Geological Magazine 141, 3, 379-387.

Nix, H., 1982. Environmental determinants of biogeography and evolution in Terra Australis.. In: Barker, W.R., Greenslade, P.J.M. (Eds.), Evolution of the Flora and fauna of Arid Australia. Peacock Publishing, Frewville, pp. 47-66.

Okuda, M., Van Vugt, N., Nakagawa, T., Ikeya, M., Hayashida, A., Yasuda, Y., Setoguchi, T., 2002. Palynological evidence for the astronomical origin of lignite-detritus sequence in the Middle Pleistocene Marathousa Member, Megalopolis, SW Greece. Earth and Planetary Science Letters 201, 143-157.

Philips, L., 1972. An application of fluorescence microscopy to the problem of derived pollen in British Pleistocene deposits. New Phytologist 71, 755-762.

Pons, A., 1998. L'histoire du genre Cedrus d'après les données paléobotaniques disponibles. Forêt méditerranéenne 19, 236-242.

Popescu, S.-M., 2001. Végétation, climat et cyclostratigraphie en Paratéthys centrale au Miocène supérieur et au Pliocène inférieur d'après la palynologie. Unpublished $\mathrm{PhD}$ Thesis, University Claude Bernard - Lyon 1, 224 pp.

Popescu, S.-M., 2006. Late Miocene and Early Pliocene environments in the southwestern Black Sea region from high-resolution palynology of DSDP Site 380A (Leg 42B). Palaeogeography, Palaeoclimatology, Palaeoecology 238, 64-77.

Popescu, S.-M., Biltekin, D., Winter, H., Suc, J.-P., Melinte-Dobrinescu, M. C., Klotz, S., Rabineau, M., Combourieu-Nebout, N., Clauzon, G., Deaconu, F., 2010. Pliocene and Lower Pleistocene vegetation and climate changes at the European scale: Long pollen records and climatostratigraphy. Quaternary International 219, 152-167.

Popescu, S.-M., Suc, J.-P., Loutre, M.-F., 2006. Early Pliocene vegetation changes forced by eccentricity-precession. Example from Southwestern Romania. Palaeogeography, Palaeoclimatology, Palaeoecology 238, 1-4, 340-348. 
Postigo Mijarra, J.M., Burjachs, F., Gómez Manzaneque, F., Morla, C., 2007. A palaeoecological interpretation of the lower-middle Pleistocene Cal Guardiola site (Terrassa, Barcelona, NE Spain) from the comparative study of wood and pollen samples. Review of Palaeobotany and Palynology 146, 247-264.

Qiao, C.-Y., Ran, J.-H., Li, Y., Wang, X.-Q., 2007. Phylogeny and Biogeography of Cedrus (Pinaceae) Inferred from Sequences of Seven Paternal Chloroplast and Maternal Mitochondrial DNA Regions. Annals of Botany 100, 573-580.

Quézel, P., Barbero, M., 1985. Carte de la végétiation potentielle de la région méditerranéenne. Feuille $\mathrm{n}^{\circ}$ 1: Méditerranée orientale. Editions du Centre National de la Recherche Scientifique, Paris, $69 \mathrm{pp}$.

Quézel, P., Médail, F., 2003. Ecologie et biogéographie des forêts du bassin méditerranéen. Elsevier, Paris, $571 \mathrm{pp}$.

Ravazzi, C., Moscariello, A., 1998. Sedimentation, palaeoenvironmental evolution and time duration of earliest Pleistocene climatic cycles in the 24-56 m FM core interval (Leffe Basin, Northern Italy). Mededelingen Nederlands Instituut voor Toegepaste Geowetenschappen TNO 60, 467-489.

Reyre, Y., 1968. La sculpture de l'exine des pollens des Gymnospermes et des Chlamydospermes et son utilisation dans l'identification des pollens fossiles. Pollen et Spores 10, 2, 198-220.

Richards, K., Bolikhovskaya, N.S., Hoogendoorn, R.M., Kroonenberg, S.B., Leroy, S.A.G., Athersuch, J., 2014. Reconstructions of deltaic environments from Holocene palynological records in the Volga delta, northern Caspian Sea. The Holocene, doi: 10.1177/0959683614540961.

Richards, K., Leroy, S., Arpe, K., Marret, F., Hoogendoorn, R., Kroonenberg, S., Athersuch, J., 2011. Fluctuations in Caspian Sea Level during the Quaternary: New Evidence from Palynology, ostracods and Climate Modelling. Congress of the American Association of Stratigraphic Palynologists, Session 86, Southampton, Abstract 1137150.

Russo Ermolli, E., 1994. Analyse pollinique de la succession lacustre pléistocène du Vallo di Diano (Campanie, Italie). Annales de la Société géologique de Belgique 117, 2, 333-354.

Russo Ermolli, E., Sardella, R., Di Maio, G., Petronio, C., Santangelo, N., 2010. Pollen and mammals from the late Early Pleistocene site of Saticula (Sant'Agata de' Goti, Benevento, Italy). Quaternary International 225, 128-137.

Sachse, M., Mohr, B., Suc, J.-P., 1999. The Makrilia-flora (Crete, Greece) - A contribution to the Neogene history of the climate and vegetation of the Eastern Mediterranean. Acta Palaeobotanica supplement 2, 365-372.

Schmittner, A., Urban, N.M., Shakun, J.D., Mahowald, N.M., Clark, P.U., Bartlein, P.J., Mix, A.C., Rosell-Melé, A., 2011. Climate Sensitivity Estimated from Temperature Reconstructions of the Last Glacial Maximum. Science 334, 1385-1388.

Sefidi, K., Marvie Mohadjer, M.R., Etemad, V., Copenheaver, C.A., 2011. Stand characteristics and distribution of a relict population of Persian ironwood (Parrotia persica C.A. Meyer) in northern Iran. Flora 206, 5, 418-422.

Şensoy, S., Ulupınar, U., 2008. İklim sınıflandırmaları. DMİ web sitesi http://www.dmi.gov.tr/iklim/iklim.aspx.

Sen, S., 1997. Magnetostratigraphic calibration of the European Neogene mammal chronology. Palaeogeography, Palaeoclimatology, Palaeoecology 133, 181-204.

Shackleton, N.-J., Hall, M.A., Pate, D., 1995. Pliocene stable isotope stratigraphy of Site 846. In/ Pisias, N.G., Mayer, L.A., Janecek, T.R., Palmer-Julson, A., van Andel, T.H. (Eds.), Proceedings of the Ocean Drilling Program, Scientific Results 138, U.S. Government Printing Office, 337-355. 
Shatilova, I., Mchedlishvili, N., Rukhadze, L., Kvavadze, E., 2011. The history oft he flora and vegetation of Georgia (South Caucasus). Lordkipanidze, D., Vekua, A. (Eds.), Georgian National Museum, Institute of Paleobiology, Tbilisi, $200 \mathrm{pp}$.

Shumilovskikh, L.S., Tarasov, P., Arz, H.W., Fleitmann, D., Marret, F., Nowaczyk, N., Plessen, B., Schlütz, F., Behling, H., 2012. Vegetation and environmental dynamics in the southern Black Sea region since 18 kyr BP derived from the marine core 22-GC3. Palaeogeography, Palaeoclimatology, Palaeoecology 337-338, 177-193.

Sickenberg, O., Becker-Platen, J.D., Benda, L., Berg, D., Engesser, B., Gaziry, W., Heissig, K., Hünerman, K.A., Sondaar, P.Y., Schmidt-Kittler, N., Staesche, K., Steffens, P., Tobien, H., 1975. Die gliederung des höheren Jungtertiärs und Altquartärs in der Türkei nach vertebraten und ihre Bedeutung für die internationale Neogen-Stratigraphie. Geologisches Jahrbuch Reihe B, 15, 167 pp.

Somot, S., Sevault, F., Déqué, M., Crépon, M., 2008. 21st century climate change scenario for the Mediterranean using a coupled atmosphere-ocean regional climate model. Global and Planetary Change 63, 112-126.

Sternitzke, H.S., 1972. Bald Cypress: Endangered or Expanding Species? Economic Botany 26, 2, 130-134.

Suballyova, D., 1997. Expression palynologique en Méditerranée des cycles glaciaireinterglaciaire arctiques anciens et cyclostratigraphie. Plio-Pléistocène de Zakynthos (coupe de la Citadelle) et de Sicile (coupe de Monte San Nicola). Unpublished PhD Thesis, University Claude Bernard - Lyon 1, 135 pp.

Subally, D., Billodeau, G., Tamrat, E., Ferry, S., Debard, E., Hillaire-Marcel, C., 1999. Cyclic climatic records during the Olduvai Subchron (uppermost Pliocene) on Zakynthos Island (Ionian Sea). Geobios 32, 6, 793-803.

Suballyova, D., Tsaila-Monopolis, S., Gautier, F., 1999. Late Plicoene cyclicity on Zakynthos Island (Eastern Mediterranean): Palynological evidence. In: Wrenn, J.H., Suc, J.-P., Leroy, S.A.G. (Eds.), The Pliocene: Time of Change. American Association of Stratigraphic Palynologists Foundation, Dallas, pp. 93-101.

Suc, J.-P., 1982a. Etude palynologique du Plio-Pléistocène de Bonaccia 1. Unpublished Industrial Report Compagnie Française des Pétroles - TOTAL, R.L. 2405, 7 pp.

Suc, J.-P., 1982b. Etude palynologique du forage Bonaccia Sud 1. Unpublished Industrial Report Compagnie Française des Pétroles - TOTAL, R.L. 2505, 5 pp.

Suc, J.-P., 1982c. Etude palynologique du forage Esmeralda 1. Unpublished Industrial Report Compagnie Française des Pétroles - TOTAL, R.L. 2693, 3 pp.

Suc, J.-P., 1984. Origin and evolution of the Mediterranean vegetation and climate in Europe. Nature 307, 429-432.

Suc, J.-P., Bessais, E., 1990. Pérennité d'un climat thermo-xérique en Sicile, avant, pendant, après la crise de salinité messinienne. Comptes-Rendus de l'Académie des Sciences de Paris 2, 310, 1701-1707.

Suc, J.-P., Clauzon, G., Bessedik, M., Leroy, S., Zheng, Z., Drivaliari, A., Roiron, P., Ambert, P., Martinell, J., Doménech, R., Matias, I., Julià, R., Anglada, R., 1992. Neogene and Lower Pleistocene in Southern France and Northeastern Spain. Mediterranean environments and climate. Cahiers de Micropaleontologie 7, 1-2, 165-186.

Suc, J.-P., Cravatte, J., 1982. Etude palynologique du Pliocène de Catalogne (nord-est de l'Espagne). Paléobiologie continentale 13, 1, 1-31.

Suc, J.-P., Bertini, A., Combourieu-Nebout, N., Diniz, F., Leroy, S., Russo-Ermolli, E., Zheng, Z., Bessais, E., Ferrier, J., 1995a. Structure of West Mediterranean vegetation and climate since 5.3 Ma. Acta zoologica cracoviense 38, 1, 3-16. 
Suc, J.-P., Combourieu-Nebout, N., Seret, G., Popescu, S.-M., Klotz, S., Gautier, F., Clauzon, G., Westgate, J., Sandhu, A.S., 2010. The Crotone series: a synthesis and new data. Quaternary International 219, 121-133.

Suc, J.-P., Diniz, F., Leroy, S., Poumot, C., Bertini, A., Dupont, L., Clet, M., Bessais, E., Zheng, Z., Fauquette, S., Ferrier, J., 1995b. Zanclean ( Brunssumian) to early Piacenzian ( early-middle Reuverian) climate from $4^{\circ}$ to $54^{\circ}$ north latitude (West Africa, West Europe and West Mediterranean areas). Mededelingen Rijks Geologische Dienst 52, 43-56.

Suc, J.-P., Fauquette, S., Bessedik, M., Bertini, A., Zheng, Z., Clauzon, G., Suballyova, D., Diniz, F., Quézel, P., Feddi, N., Clet, M., Bessais, E., Bachiri Taoufiq, N., Méon, H., Combourieu-Nebout, N., 1999. Neogene vegetation changes in West European and West circum-Mediterranean areas. In: Agusti, J., Rook, L., Andrews, P. (Eds.), Hominid Evolution and Climate in Europe, 1. Climatic and Environmental Change in the Neogene of Europe. Cambridge University Press, Cambridge, pp. 370-385.

Suc, J.-P., Fauquette, S., Popescu, S.-M., 2004. L’investigation palynologique du Cénozoïque passe par les herbiers. In : Pierrel, R., Reduron, J.-P. (Eds.), Les herbiers: un outil d'avenir. Tradition et modernité. Association française pour la Conservation des Espèces Végétales, Villers-lès-Nancy, pp. 67-87.

Suc, J.-P., Popescu, S.-M., 2005. Pollen records and climatic cycles in the North Mediterranean region since 2.7 Ma. Geological Society of London Spécial Publication, 247, 147-158.

Svenning, J.-C., 2003. Deterministic Plio-Pleistocene extinctions in the European cool-temperate tree flora. Ecology Letters 6, 646-653.

Thanikaimoni, G., 1987. Mangrove palynology. Institut Français de Pondichéry, Travaux de la section Scientifique et Technique 24, 1-100.

Thompson, R.S., Anderson, K.H., Bartlein, P.J., 2000. Atlas of Relations Between Climatic Parameters and Distributions of Important Trees and Shrubs in North America Hardwoods. U.S. Geological Survey Professional Paper 1650, B, 1-423.

Tiedemann, R., Sarnthein, M., Shackleton, N.J., 1994. Astronomic timescale for the Pliocene Atlantic $\delta^{18} \mathrm{O}$ and dust flux records of Ocean Drilling Program site 659. Paleoceanography 9, 4, 619-638.

Tomlinson, P.B., 1986. The botany of mangroves. Cambridge University Press, Tropical Biology Series, Cambridge, 419pp.

Tzedakis, P.C., 1993. Long-term tree populations in northwest Greece through multiple Quaternary climatic cycles. Nature 364, 437-440.

Tzedakis, P.C., 1994. Vegetation change through glacial-interglacial cycles: a long pollen sequence perspective. Philosophical Transactions of the Royal Society of London B, 345, 403-432.

Tzedakis, P.C., Frogley, M.R., Heaton, T.H.E., 2003. Last Interglacial conditions in southern Europe: evidence from Ioannina, northwest Greece. Global and Planetary Change 36, 157170.

Tzedakis, P.C., Hooghiemstra, H., Pälike, H., 2006. The last 1.35 million years at Tenaghi Philippon, revised chronostratigraphy and long-term vegetation trends. Quaternary Science Reviews 25, 3416-3430.

Urban, B., Fuchs, M., 2005. Late Pleistocene vegetation of the basin of Phlious, NEPeloponnese, Greece. Review of Palaeobotany and Palynology 137, 15-29.

Valsecchi, V., Sanchez Goñi, M.F., Londeix, L., 2012. Vegetation dynamics in the Northeastern Mediterranean region during the past $23000 \mathrm{yr}$ : insights from a new pollen record from the Sea of Marmara. Climate of the Past 8, 1941-1956.

Van der Wiel, A.M., Wijmstra, T.A., 1987a. Palynology of the lower part (78-120 m) of the core Tenaghi Philippon II, Middle Pleistocene of Macedonia, Greece. Review of Palaeobotany and Palynology 52, 73-88. 
Van der Wiel, A.M., Wijmstra, T.A., 1987b. Palynology of the 112.8-197.8 m interval of the core Tenaghi Philippon III, Middle Pleistocene of Macedonia. Review of Palaeobotany and Palynology 52, 89-117.

Van Gijzel, P., 1967. Palynology and fluorescence microscopy. Review of Palaeobotany and Palynology 2, 49-79.

Van Vugt, N., Steenbrink, J., Langereis, C.G., Hilgen, F.J., Meulenkamp, J.E., 1998. Magnetostratigraphy-based astronomical tuning of the early Pliocene lacustrine sediments of Ptolemais (NW Greece) and bed-to-bed correlation with the marine record. Earth and Planetary Science Letters 164, 535-551.

Velitzelos, E., Gregor, H.-J., 1990. Some Aspects of the Neogene Floral History in Greece. Review of Palaeobotany and Palynology 62, 291-307.

Wang, C.W., 1961. The forests of China with a survey of grassland and desert vegetation. Maria Moors Cabot Foundation, 5. Harvard University, Cambridge, Massachusetts, 313 pp.

Wang, Y., Cheng, H., Edwards, R.L., Kong, X., Shao, X., Chen, S., Wu, J., Jiang, X., Wang, X., An, Z., 2008. Millennial- and orbital-scale changes in the East Asian monsoon over the past 224,000 years. Nature 451, 1090-1093.

Wendelbo, P., 1968. Hamamelidaceae. In: Rechinger, K.H. (Ed.), Flora Iranica 53, Akademische Druck - u. Verlagsanstalt, Graz, p. 3.

Wijmstra, T.A., 1969. Palynology of the first 30 metres of a $120 \mathrm{~m}$ deep section in northern Greece. Acta Botanica Neerlandica 18, 4, 511-527.

Wijmstra, T.A., Smit, A., 1976. Palynology of the middle part (30-78 metres) of the $120 \mathrm{~m}$ deep section in northern Greece (Macedonia). Acta Botanica Neerlandica 25, 4, 297-312.

Willis, K.J., Niklas, K.J., 2004. The role of Quaternary environmental change in plant macroevolution: the exception or the rule? Philosophical Transactions of the Royal Society of London Biological Sciences 359(1442), 159-172.

Yavuz-Iş1k, N., 2007. Pollen analysis of coal-bearing Miocene sedimentary rocks from the Seyitömer Basin (Kütahya), Western Anatolia. Geobios 40, 701-708.

Yavuz-Iş1k, N., 2008. Vegetation and climatic investigations in the Early Miocene lacustrine deposits of the Güvem Basin (Galatean Volcanic Province), NW Central Anatolia, Turkey. Review of Palaeobotany and Palynology 150, 130-139.

Yavuz-Iş1k, N., Toprak, V., 2010. Palynostratigraphy and vegetation characteristics of Neogene continental deposits interbedded with the Cappodocia ignimbrites (Central Anatolia, Turkey). International Journal of Earth Sciences 99, 1887-1897.

Zachos, J., Pagani, M., Sloan, L., Thomas, E., Billups, K., 2001. Trends, rhythms, and aberrations in global climate 65 Ma to present. Science 292, 686-693.

Zagwijn, W.H., 1960. Aspects of the Pliocene and Early Pleistocene vegetation in The Netherlands. Mededelingen van de Geologische Stichting C, 3, 1, 5, 5-78.

Zohary, M., 1973. Geobotanical Foundations of the Middle East. Fischer, Stuttgart, 739 pp. 

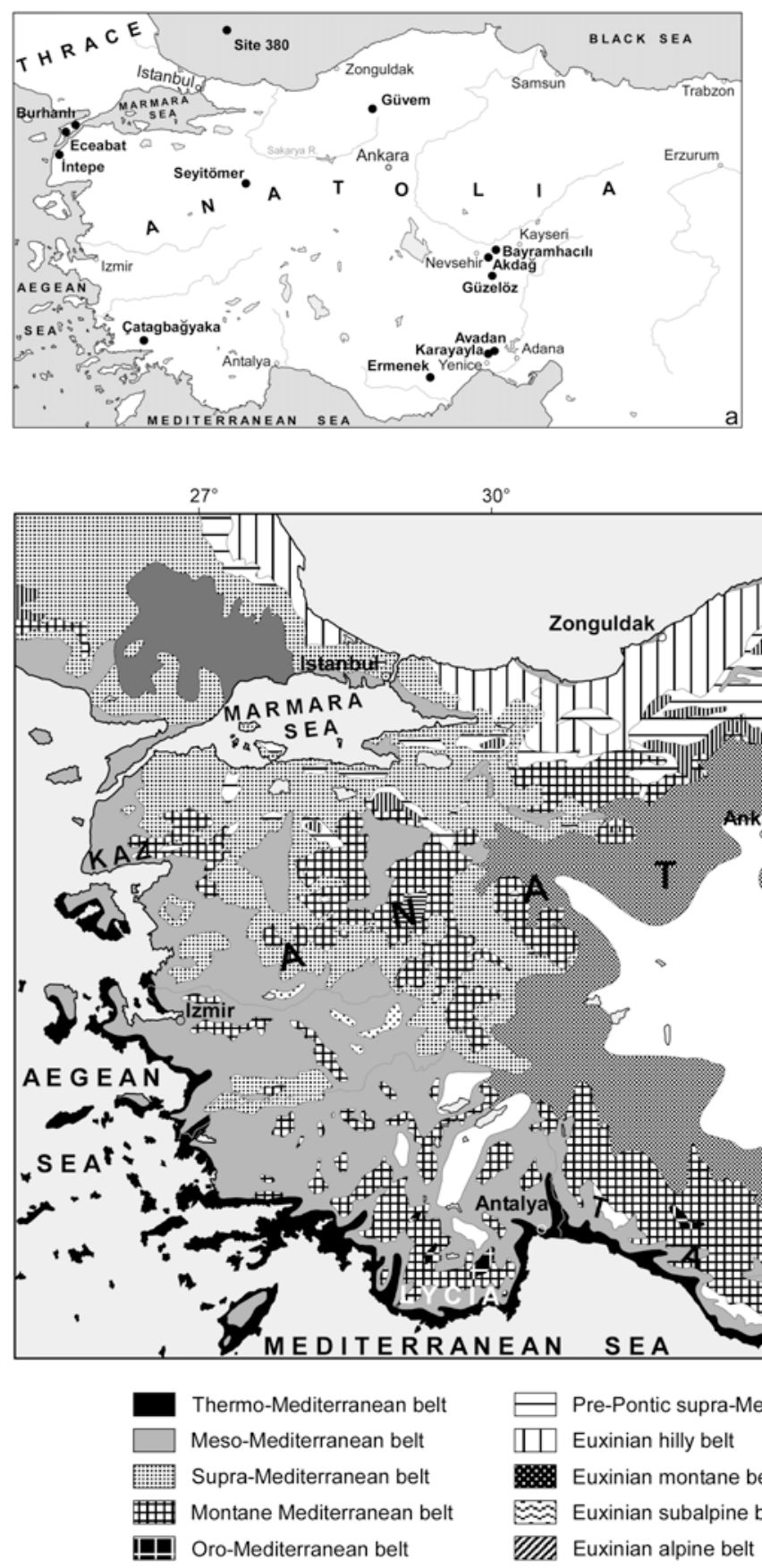

$33^{\circ}$

曲册曲

\#nkara

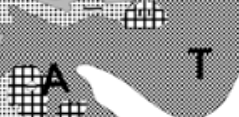

I】 Euxinian hilly belt

Euxinian montane belt

Euxinian subalpine belt

WIIs Euxinian alpine belt

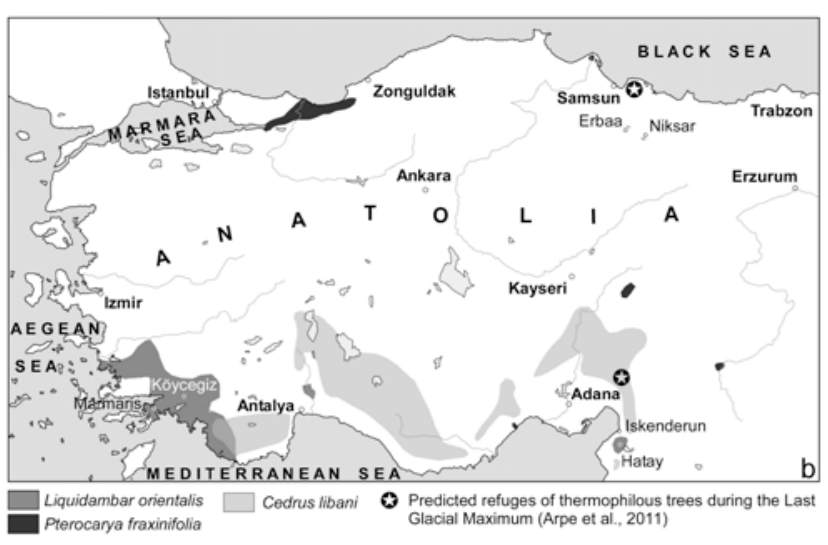

$36^{\circ}$

B LACK SEA

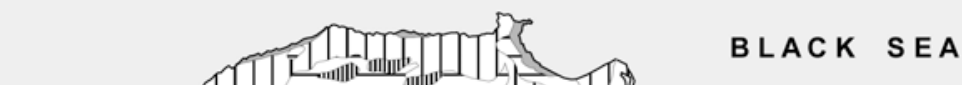

Zonguldak $T$ | Trabzon

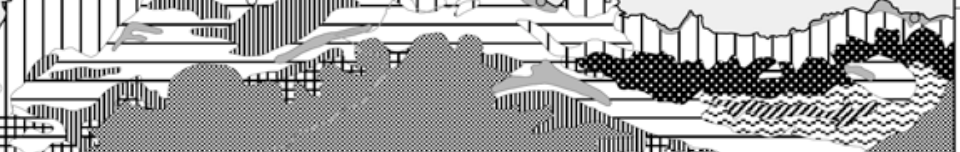

$T \%$

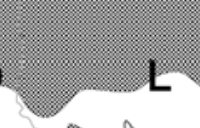

- 1 A

Erzurum
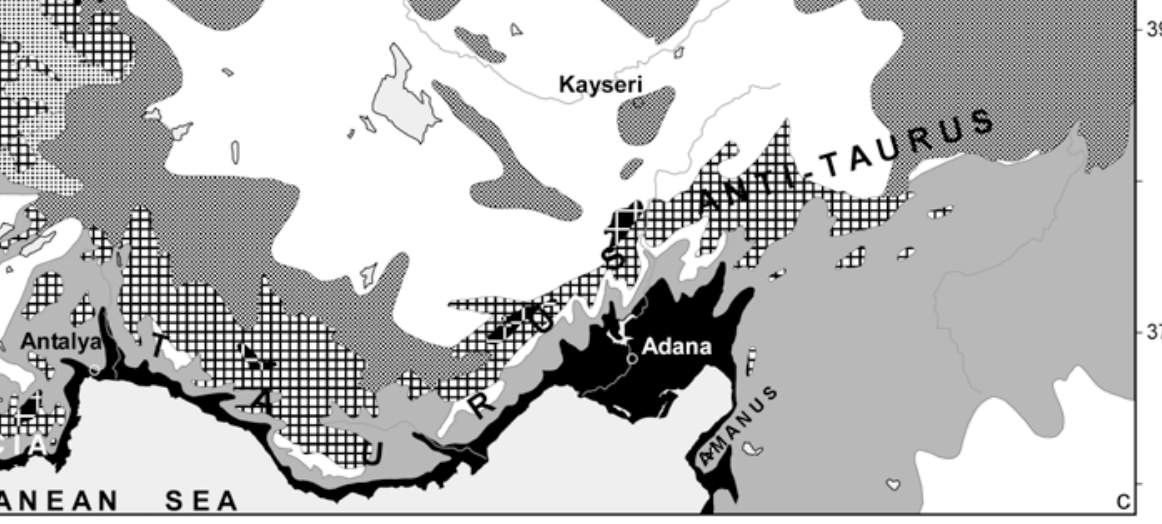

$\square$ Pre-Pontic supra-Mediterranean belt

||⿴囗⿰丿丨川|II Montane belt

Pre-steppic vegetation

Eastern Thrace steppes and meadows

Anatolian and Irano-Touranian steppes

Fig. 1. Location and vegetation maps.

a, Study area and location of pollen sites (black dots);

b, Present-day distribution of Liquidambar orientalis, Pterocarya fraxinifolia and Cedrus libani in Anatolia (from: Quézel and Médail, 2003), compared to the predicted location of 
thermophilous trees during the Last Glacial Maximum according to the model T106EH5 developed by Arpe et al. (2011);

c, Simplified present-day vegetation map of Anatolia (from: Quézel and Barbero, 1985).

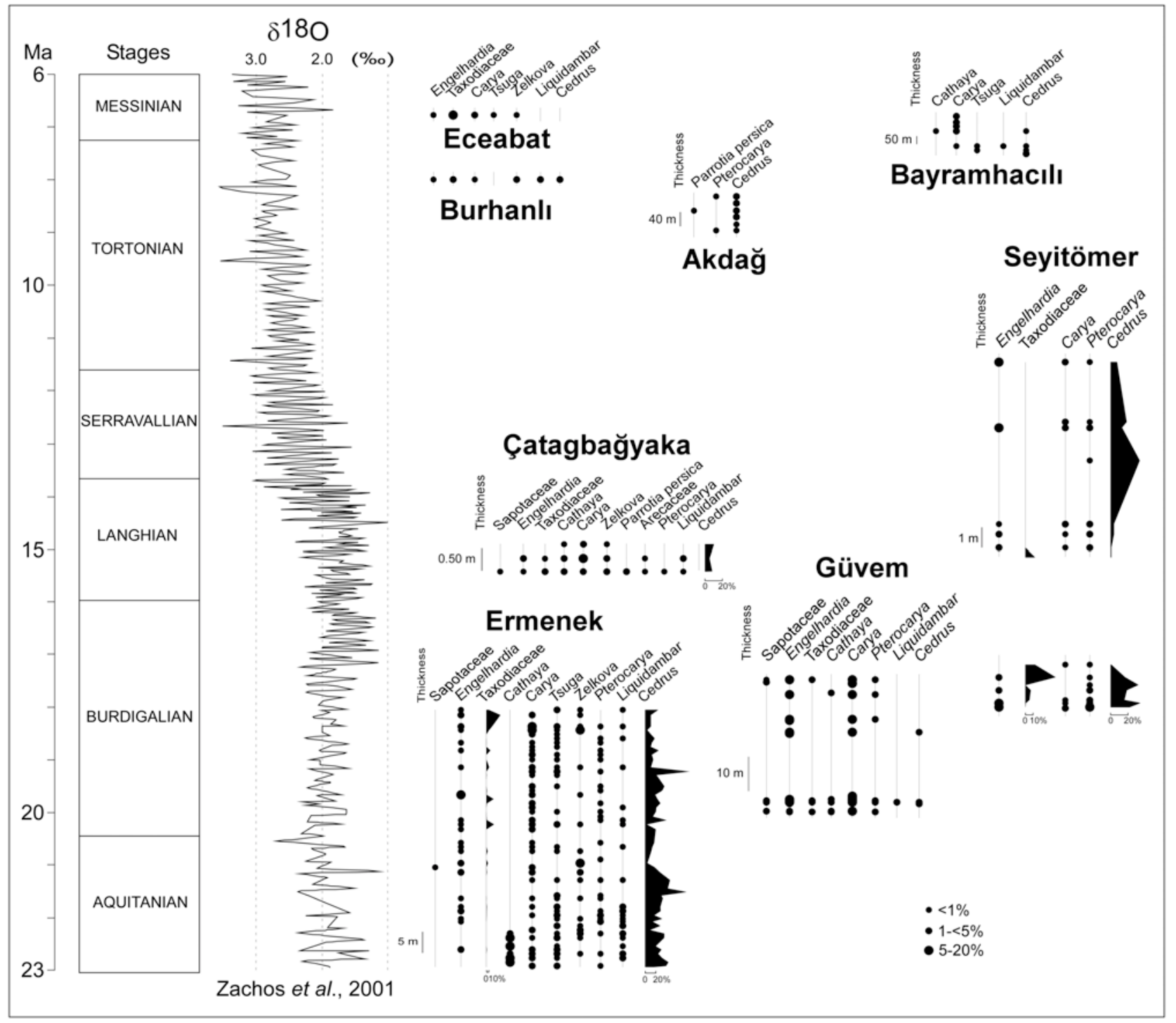

Fig. 2. Selected taxa from Anatolian pollen records chronologically distributed between 23 and 6 Ma. A curve replaces solid dots for Taxodiaceae and Cedrus when a continuous record with significant percentage is available. The chronostratigraphic timescale is from Lourens et al. (2005). 


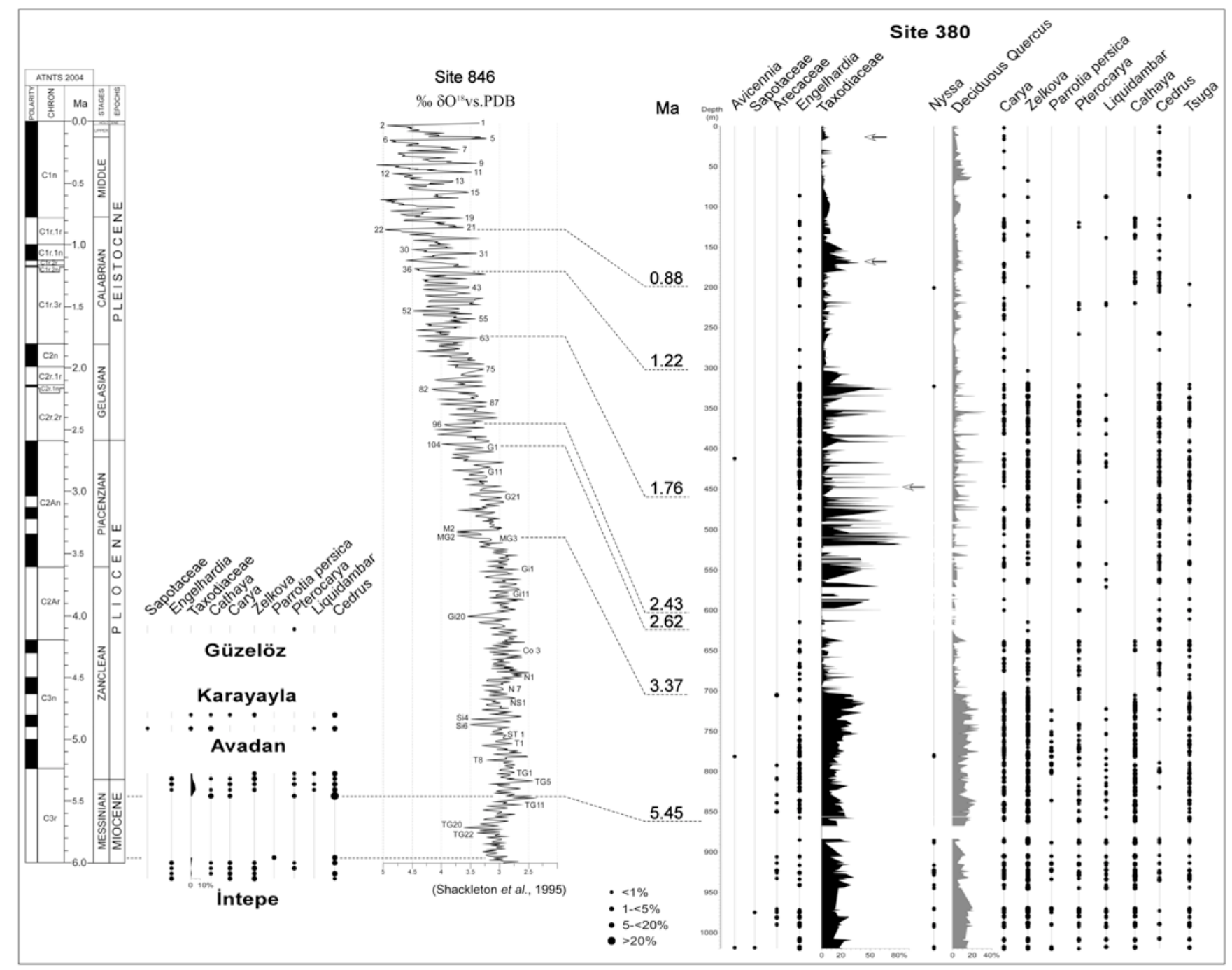

Fig. 3. Selected taxa from Anatolian pollen records chronologically distributed between $6 \mathrm{Ma}$ and Present. A curve is drawn for Taxodiaceae. The major chronostratigraphic relationships between pollen records and the reference oxygen isotope curve are established by MelinteDobrinescu et al. (2009) for İntepe and Popescu et al. (2010) for Site 380. Arrows indicate the origin of pollen photographs of Taxodiaceae shown in Plate I. The chronostratigraphic timescale is from Lourens et al. (2005). White spaces between continuous records (Taxodiaceae, deciduous Quercus) correspond to unrecovered sediment and/or non sampled slump intervals, and detritals such as the Pebly Breccia (874.00-883.50 m). 


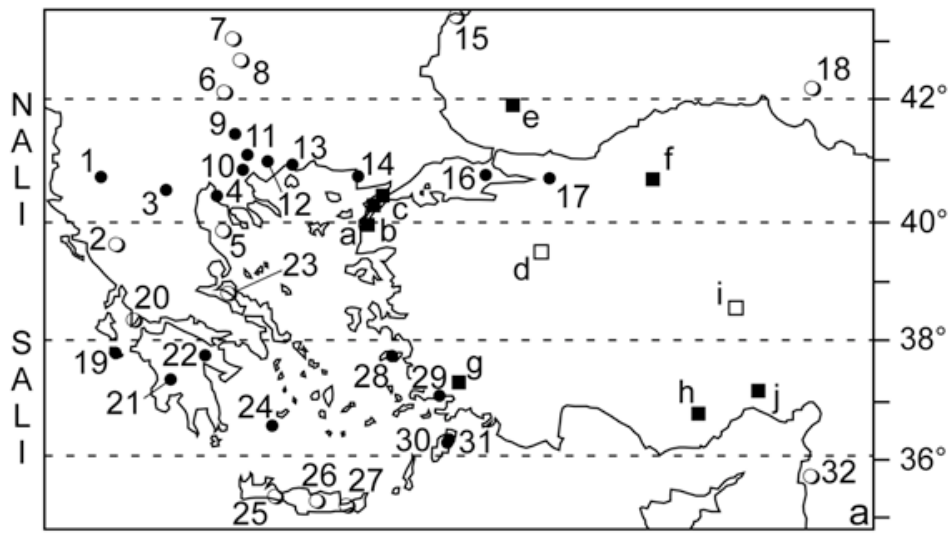

North latitudinal interval (NLI): $40^{\circ}-42^{\circ} \mathrm{N}$

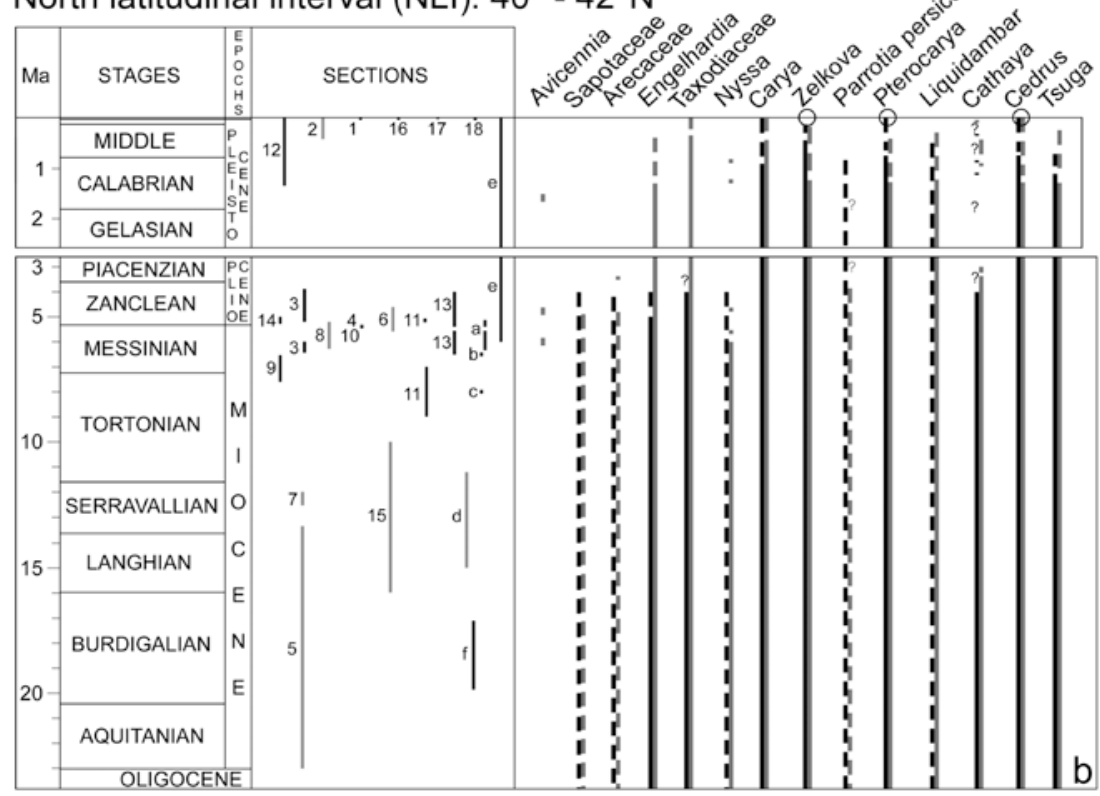

South latitudinal interval (SLI): $36^{\circ}-38^{\circ} \mathrm{N}$

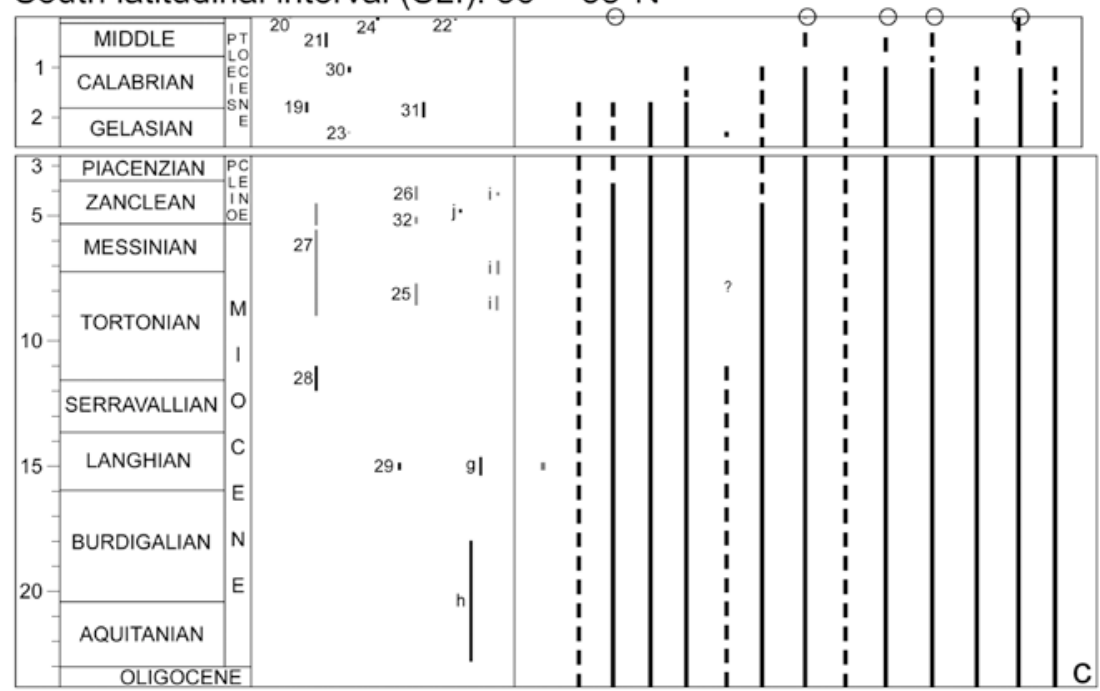


Fig. 4. Compared geographic and chronological distribution of some taxa within the latitudinal range of Anatolia ( $c a .36^{\circ}$ to $c a .42^{\circ}$ North) for the last $23 \mathrm{Ma}$.

a, Location map of the selected pollen floras (for names, associated numbers and references: see Table 1). Black dots: compared pollen floras located within the two latitudinal intervals $40-42^{\circ} \mathrm{N}$ (North Anatolia latitudinal interval: NALI) and $36-38^{\circ} \mathrm{N}$ (South Anatolia latitudinal interval: SALI); circles: compared pollen floras located out of these latitudinal intervals; black squares: new pollen floras presented in this work located within these latitudinal intervals (a, İntepe; $b$, Eceabat; c, Burhamlı; e, Site 380; f, Güvem; g, Çatakbağyaka; h, Ermenek; j, Avadan and Karayayla); blank squares: new pollen floras presented in this work located out of these latitudinal intervals (d, Seyitömer; i, Bayramhacılı, Akdağ, and Güzelöz).

$\mathrm{b}$ and $\mathrm{c}$, Chronological location of pollen floras (in light grey, localities out of the concerned latitudinal interval) and chronological extension of some taxa within (and close to) the latitudinal interval $40^{\circ}-42^{\circ} \mathrm{N}$ (NALI) and $36^{\circ}-38^{\circ} \mathrm{N}$ (SALI), respectively. The chronological scale is doubled for the time-interval 0-2.6 Ma. Continuous vertical lines indicate constant records attested by significant amount of pollen grains; discontinuous vertical lines indicate intermittent records characterized by low amount of pollen grains. Circles at present time point out elements still living in Anatolia.

b, NALI: $40^{\circ}-42^{\circ} \mathrm{N}$. Thanks to the new pollen data presented in this paper, the history of taxa can be reconstructed for the last $23 \mathrm{Ma}$ and in detail for the last $6 \mathrm{Ma}$, expressed by the vertical (continuous or discontinuous) dark grey lines. The black vertical lines synthesize the pre-existing pollen data at the scale of the considered latitudinal interval.

c, SALI: $36^{\circ}-38^{\circ} \mathrm{N}$. Only black vertical lines synthesize all the available pollen data at the scale of the considered latitudinal interval. 

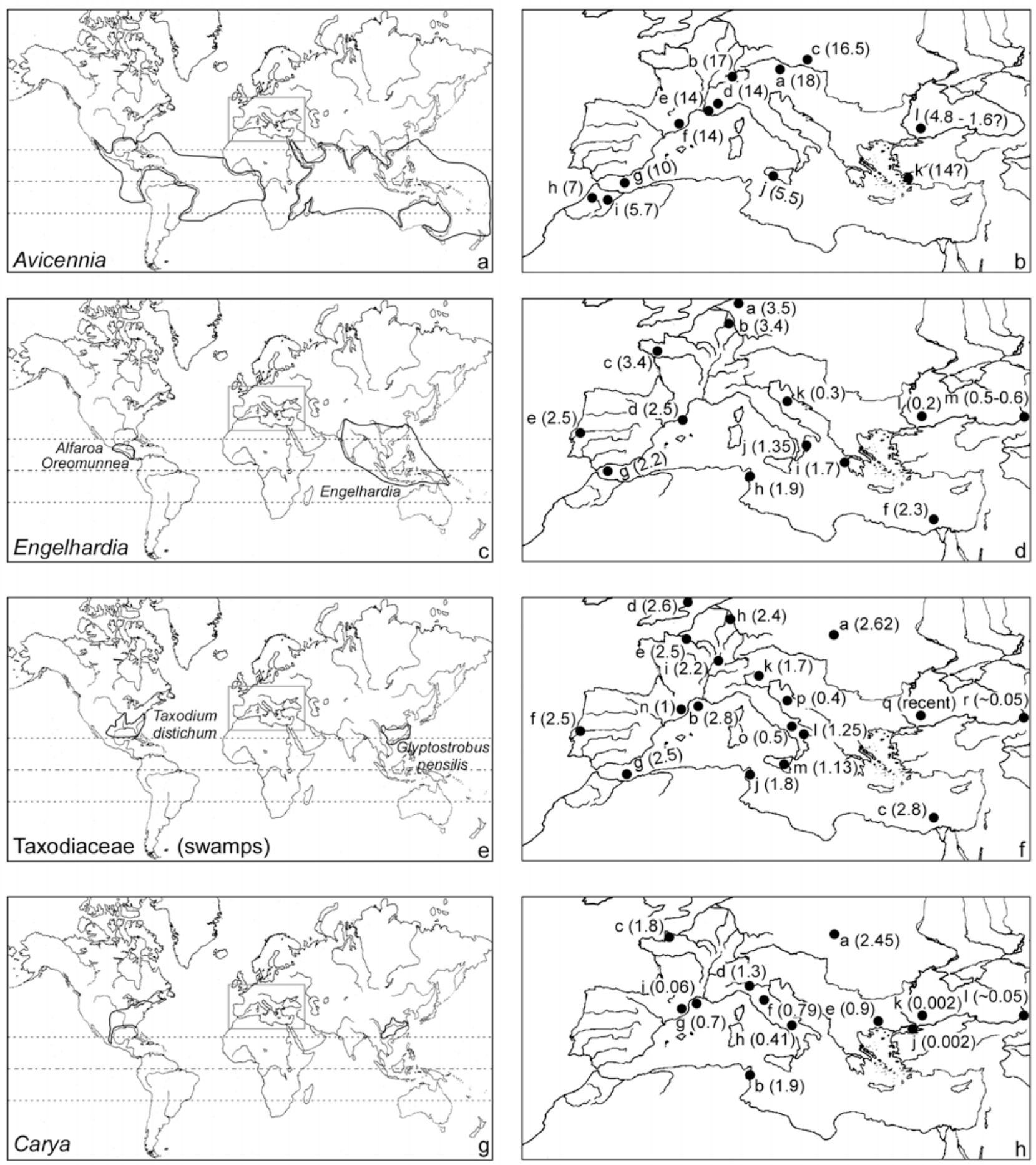

Fig. 5. Present-day distribution maps of four reference taxa (a, Avicennia; c, Engelhardia; e, Taxodiaceae inhabiting swamps; g, Carya) and their last pollen record (ranked by decreasing 
age, indicated in brackets after the locality reference letter) in Europe (b, Avicennia; d, Engelhardia; f, Taxodiaceae inhabiting swamps; h, Carya), North Africa and Near East (see Table 2 for list of localities and relevant literature).
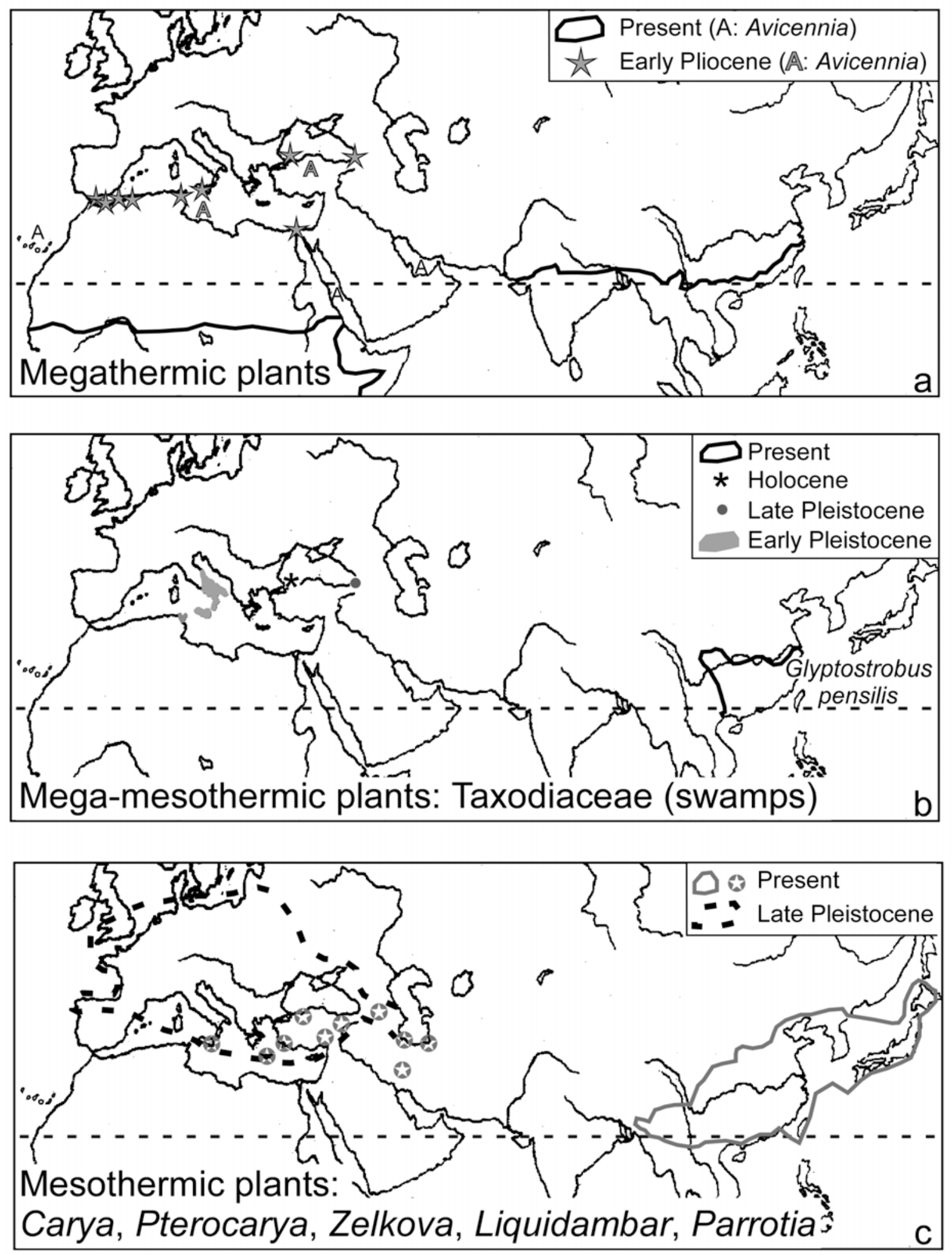
Fig. 6. Proposed past refuge areas compared to present distribution of some thermophilous taxa or groups of taxa in Eurasia.

a, Megathermic elements;

b, Taxodiaceae (swamp elements);

c, Mesothermic elements (Carya, Pterocarya, Zelkova, Liquidambar, Parrotia).

\begin{tabular}{|c|c|c|}
\hline $\mathbf{N}^{\circ}$ & Localities & References \\
\hline 1 & Maliq & Denèfle et al. (2000) \\
\hline 2 & Ioannina & Tzedakis $(1993,1994)$ \\
\hline 3 & Ptolemais & $\begin{array}{l}\text { Ioakim (1984) } \\
\text { Klosterboer-van Hoeve (2000) } \\
\text { Biltekin (2010) }\end{array}$ \\
\hline 4 & Trilophos & Biltekin (2010) \\
\hline 5 & Nireas 1 & $\begin{array}{l}\text { Drivaliari (1993) } \\
\text { Jiménez-Moreno et al. (2007) }\end{array}$ \\
\hline 6 & Ravno Pole & $\begin{array}{l}\text { Drivaliari (1993) } \\
\text { Jiménez-Moreno et al. (2007) }\end{array}$ \\
\hline 7 & Ruzhintsi & $\begin{array}{l}\text { Jiménez-Moreno (2005) } \\
\text { Jiménez-Moreno et al. (2007) }\end{array}$ \\
\hline 8 & Beli Breg & Ivanov et al. (2007) \\
\hline 9 & Sandanski & $\begin{array}{l}\text { Ivanov (2003) } \\
\text { Jiménez-Moreno et al. (2007) }\end{array}$ \\
\hline 10 & Lion of Amphipoli & Suc (unpublished) \\
\hline 11 & Serres & $\begin{array}{l}\text { Karistineos \& Ioakim (1989) } \\
\text { Suc (unpublished) }\end{array}$ \\
\hline 12 & Tenaghi Philippon & $\begin{array}{l}\text { Wijmstra (1969) } \\
\text { Wijmstra \& Smit (1976) } \\
\text { Van der Wiel \& Wijmstra (1987a, b) } \\
\text { Tzedakis et al. (2006) }\end{array}$ \\
\hline 13 & Nestos 2 & $\begin{array}{l}\text { Drivaliari (1993) } \\
\text { Jiménez-Moreno et al. (2007) }\end{array}$ \\
\hline 14 & Enez & $\begin{array}{l}\text { Melinte-Dobrinescu et al. (2009) } \\
\text { Biltekin (2010) }\end{array}$ \\
\hline 15 & Balchik C136A & Ivanov et al. (2007) \\
\hline 16 & MAR98-9 & Mudie et al. (2002) \\
\hline 17 & Lake Sapanca & Leroy et al. $(2009,2010)$ \\
\hline 18 & Black sea B7 & Mudie et al. (2002) \\
\hline 19 & Zakynthos Citadel & $\begin{array}{l}\text { Suballyova (1997) } \\
\text { Subally et al. (1999) }\end{array}$ \\
\hline 20 & $\begin{array}{l}\text { Acheloos Delta } \\
\text { (holes OEN } 1 \& 2 \text { ) }\end{array}$ & Fouache et al. (2005) \\
\hline 21 & Megalopolis & Okuda et al. (2002) \\
\hline 22 & Core A11 & Urban \& Fuchs (2005) \\
\hline 23 & Zeli & Ioakim \& Rondoyani (1988) \\
\hline 24 & Core C69 & Geraga et al. (2005) \\
\hline 25 & Makrilia & Sachse et al. (1999) \\
\hline 26 & Aghios Vlassios & $\begin{array}{l}\text { Drivaliari (1993) } \\
\text { Jiménez-Moreno et al. (2007) }\end{array}$ \\
\hline 27 & Sitia & Ioakim et al. (1997) \\
\hline 28 & Mavradzei & Ioakim \& Solounias (1985) \\
\hline 29 & Kultak - Muğla - Milas & Kayseri-Özer (2014) \\
\hline 30 & Tsampika & Joannin et al. (2007) \\
\hline 31 & Cape Vagia & $\begin{array}{l}\text { Buisine (2000) } \\
\text { Cornée et al. (2006) }\end{array}$ \\
\hline
\end{tabular}


Table 1. Pollen localities considered for comparison with the present-work pollen floras. Numbers refer to Figure 4.

\begin{tabular}{|c|c|c|c|}
\hline $\mathbf{N}^{\circ}$ & Regions & Localities & References \\
\hline Avicennia & Present distribution & & Tomlinson (1986) \\
\hline A & Central Europe & Strass-Eberschwang & Jiménez-Moreno et al. (2008) \\
\hline $\mathrm{B}$ & Central Europe & Häutlingen & Jiménez-Moreno (2005) \\
\hline $\mathrm{C}$ & Central Europe & Göllersdorf & Jiménez-Moreno et al. (2008) \\
\hline $\mathrm{D}$ & $\begin{array}{l}\text { Southeastern } \\
\text { France }\end{array}$ & Châteauredon & Besson et al. (2005) \\
\hline $\mathrm{E}$ & & Bayanne & Besson et al. (2005) \\
\hline $\mathrm{F}$ & Catalonia & La Rierussa & $\begin{array}{l}\text { Bessedik (1985) } \\
\text { Jiménez-Moreno (2005) }\end{array}$ \\
\hline $\mathrm{G}$ & Alboran Sea & Andalucia A1 & $\begin{array}{l}\text { Jiménez-Moreno (2005) } \\
\text { Jiménez-Moreno et al. (2010) }\end{array}$ \\
\hline $\mathrm{H}$ & Southern Rif & NRT2 & $\begin{array}{l}\text { Bachiri Taoufiq (2000) } \\
\text { Bachiri Taoufiq et al. (2000) }\end{array}$ \\
\hline $\mathrm{I}$ & Southern Rif & Col de Touahar & $\begin{array}{l}\text { Bachiri Taoufiq (2000) } \\
\text { Bachiri Taoufiq et al. (2000) }\end{array}$ \\
\hline $\mathrm{J}$ & Sicily & Eraclea Minoa & $\begin{array}{l}\text { Suc and Bessais (1990) } \\
\text { Fauquette et al. (2006) }\end{array}$ \\
\hline $\mathrm{K}$ & Southwest Turkey & Kultak - Muğla - Milas & Kayseri-Özer (2014) \\
\hline $\mathrm{L}$ & Black Sea & Site 380 & $\begin{array}{l}\text { Popescu et al. (2010) } \\
\text { Biltekin (2010) }\end{array}$ \\
\hline Engelhardia & Present distribution & & $\begin{array}{l}\text { Aubréville (1974) } \\
\text { An-Ming (1982) }\end{array}$ \\
\hline $\mathrm{A}$ & Hanover & Oldenswort 9 & Menke (1975) \\
\hline B & The Netherlands & Koningsbosch & Zagwijn (1960) \\
\hline $\mathrm{C}$ & Brittany & Saint-Jean la Poterie & Fourniguet et al. (1989) \\
\hline $\mathrm{D}$ & Catalonia & Garraf 1 & Suc and Cravatte (1982) \\
\hline $\mathrm{E}$ & Portugal & Rio Maior F58 and F16 & Diniz (1984) \\
\hline $\mathrm{F}$ & Offshore Nile Delta & NAF 2 & Drivaliari (1993) \\
\hline $\mathrm{G}$ & Alboran Sea & Andalucia G1 & Feddi et al. (2011) \\
\hline $\mathrm{H}$ & Gulf of Hammamet & Jiriba 1 & Mriqo (2010) \\
\hline $\mathrm{I}$ & Zakynthos Island & Citadel & Suballyova (1997) \\
\hline $\mathrm{J}$ & Calabria & Vrica C & Combourieu-Nebout (1990) \\
\hline K & North Adriatic Sea & $\begin{array}{l}\text { Bonaccia 1, Bonaccia Sud } \\
\text { 1, Esmeralda } 1\end{array}$ & Suc (1982a, b, c) \\
\hline $\mathrm{L}$ & Black Sea & Site 380 & This paper \\
\hline $\mathrm{M}$ & Black Sea & West Georgia & Shatilova et al. (2011) \\
\hline $\begin{array}{l}\text { Taxodiaceae } \\
\text { (swamps) }\end{array}$ & Present distribution & & $\begin{array}{l}\text { Sternitzke (1972) } \\
\text { Fang et al. (2011) }\end{array}$ \\
\hline A & Poland & Wólka Ligezowska & Winter in Popescu et al. (2010) \\
\hline B & Gulf of Lions & Autan 1 & $\begin{array}{l}\text { Cravatte and Suc (1981) } \\
\text { Suc et al. (1992) }\end{array}$ \\
\hline $\mathrm{C}$ & Offshore Nile Delta & NAF 2 & Drivaliari, 1993 \\
\hline $\mathrm{D}$ & East Anglia & Several localities & Gibbard et al. (1991) \\
\hline $\mathrm{E}$ & Normandy & La Londe K & Clet-Pellerin et al. (1999) \\
\hline $\mathrm{F}$ & Portugal & Rio Maior F58 and F16 & Diniz (1984) \\
\hline $\mathrm{G}$ & Alboran Sea & Nador 1 & Feddi et al. (2011) \\
\hline
\end{tabular}




\begin{tabular}{|l|l|l|l|}
\hline J & Gulf of Hammamet & Jiriba 1 & Mriqo (2010) \\
\hline K & Po Valley & Leffe & $\begin{array}{l}\text { Ravazzi and Moscariello } \\
\text { (1998) }\end{array}$ \\
\hline L & Calabria & Montalbano Jonico & Joannin et al. (2008) \\
\hline M & Sicily & Caltagirone & Dubois (2001) \\
\hline N & Catalonia & Cal Guardiola & Postigo Mijarra et al. (2007) \\
\hline O & Campania & Vallo di Diano & Russo Ermolli (1994) \\
\hline P & North Adriatic Sea & Bonaccia 1, Bonaccia Sud 1 & Suc (1982a, b) \\
\hline Q & Black Sea & Site 380 & This paper \\
\hline R & Black Sea & West Georgia & Shatilova et al. (2011) \\
\hline Carya & Present distribution & & $\begin{array}{l}\text { An-Ming (1982) } \\
\text { Thompson et al. (2000) }\end{array}$ \\
\hline A & Poland & Wólka Liezawska & Winter in Popescu et al. (2010) \\
\hline B & Gulf of Hammamet & Jiriba 1 & Mriqo (2010) \\
\hline C & Normandy & Bosq d'Aubigny & $\begin{array}{l}\text { Clet-Pellerin (1983) } \\
\text { Clet-Pellerin et al. (1985) }\end{array}$ \\
\hline D & Po Valley & Stirone & Bertini (2001) \\
\hline E & Northen Greece & Tenaghi Philippon & $\begin{array}{l}\text { Van der Wiel and Wijmstra } \\
\text { (1987b) }\end{array}$ \\
\hline F & Central Italy & Valdarno & Albianelli et al. (1995) \\
\hline G & Catalonia & Bòbila Ordis & $\begin{array}{l}\text { Julà Bruguès and Suc (1980) } \\
\text { Suc et al. (1992) } \\
\text { Leroy (2008) }\end{array}$ \\
\hline H & & & $\begin{array}{l}\text { Russo Ermolli (1994) } \\
\text { Russo Ermolli et al. (2010) }\end{array}$ \\
\hline I & Calabria & Vallo di Diano & Suc et al. (in progress) \\
\hline J & Budie et al. (2002) \\
\hline K & Gulf of Lions & PRGL1-4 & This paper \\
\hline L & Marmara Sea & MAR 98-9 & Shatilova et al. (2011) \\
\hline
\end{tabular}

Table 2. References for present-day distribution of Avicennia, Engelhardia, Taxodiaceae swamps, and Carya. Pollen localities considered for comparison. Letters refer to Figure 5. 

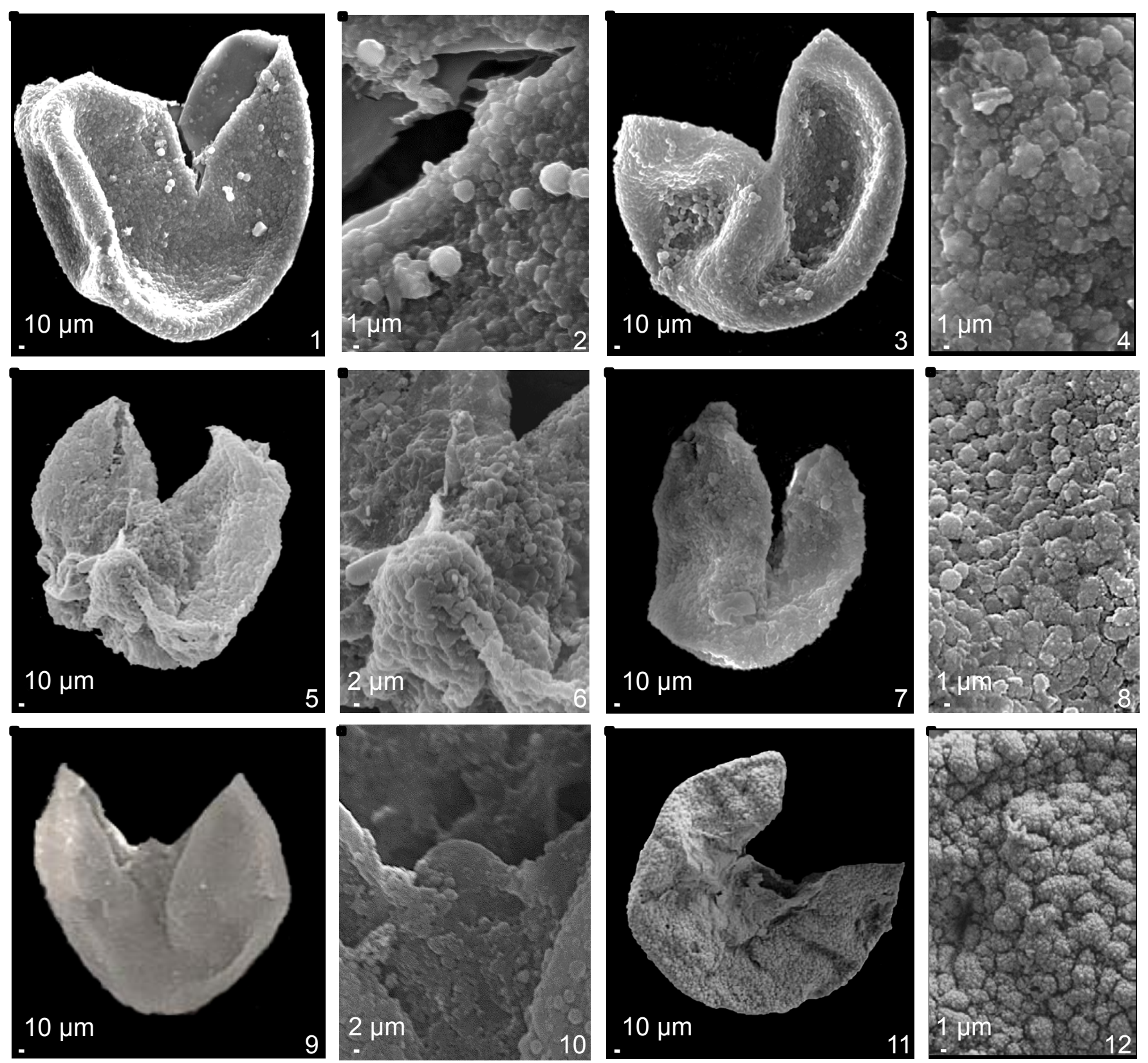

Plate I. Present and fossil pollen grains of Taxodiaceae.

1 to 4, Two modern pollen grains of Glyptostrobus pensilis (Staunton ex D. Don) K. Koch, originating from China (Herbarium of the Sun Yat-sen University, Guangzhou; sample number: 28781; originating from the Herbarium of the Lingnam University, China): 1, General view (x2000); 2, Detail of the sculpture (x12000); 3, General view of another grain (x2000); 4, Detail of its sculpture (x12000).

5 and 6, Pollen grain from Site 380 (448 $\mathrm{m}$ depth, lower Pleistocene): 5, General view showing the papilla (x2000); 6, Detail of the sculpture in the papilla area (x6000). 
7 and 8, Pollen grain from Site 380 (448 m depth, lower Pleistocene): 7, General view (x2000); 8 , Detail of the sculpture (x12000).

9 and 10, Pollen grain from Site 380 (168 m depth, Middle Pleistocene): 9, General view showing the papilla (x2000); 10, Detail of the sculpture in the papilla area (x6000).

11 and 12, Pollen grain from Site 380 (13.50 m depth, Holocene): 11, General view (x2000); 12,

Detail
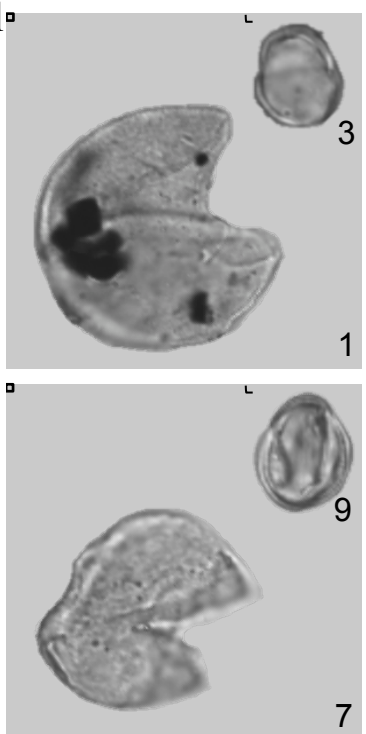

7
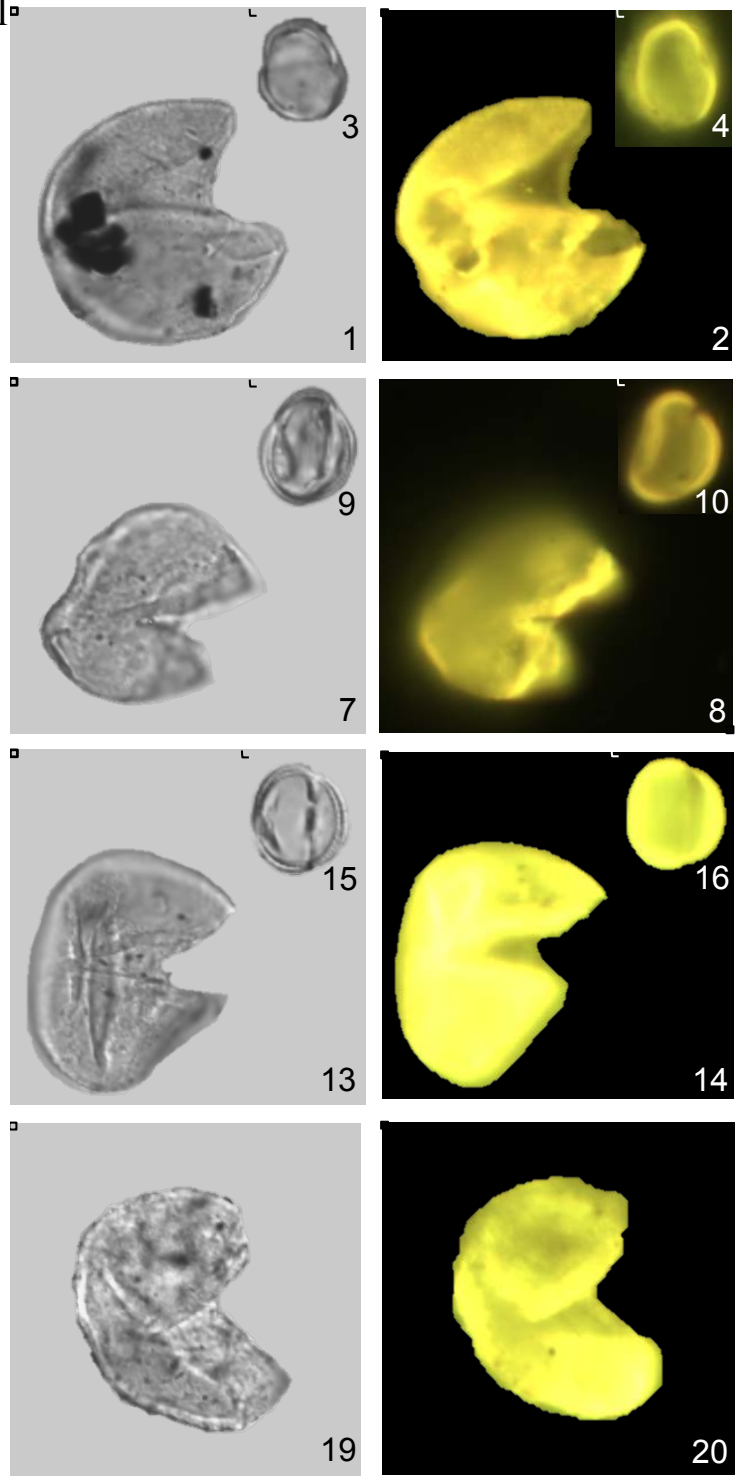
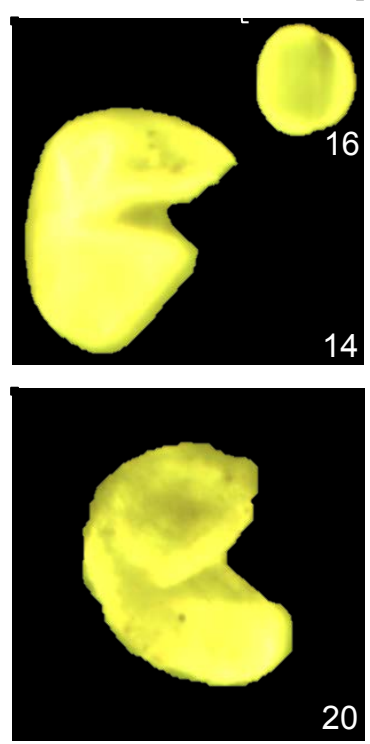

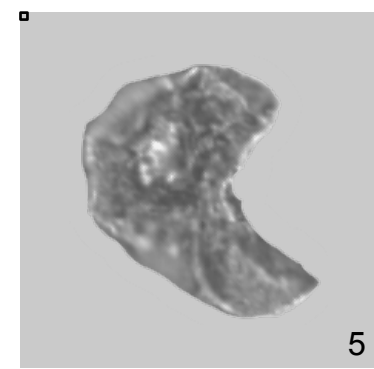

5
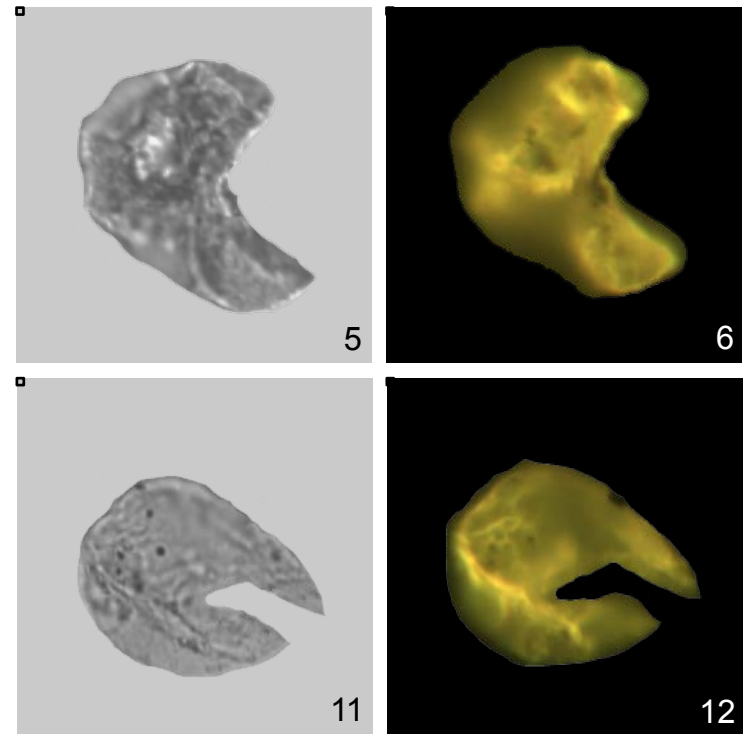

11
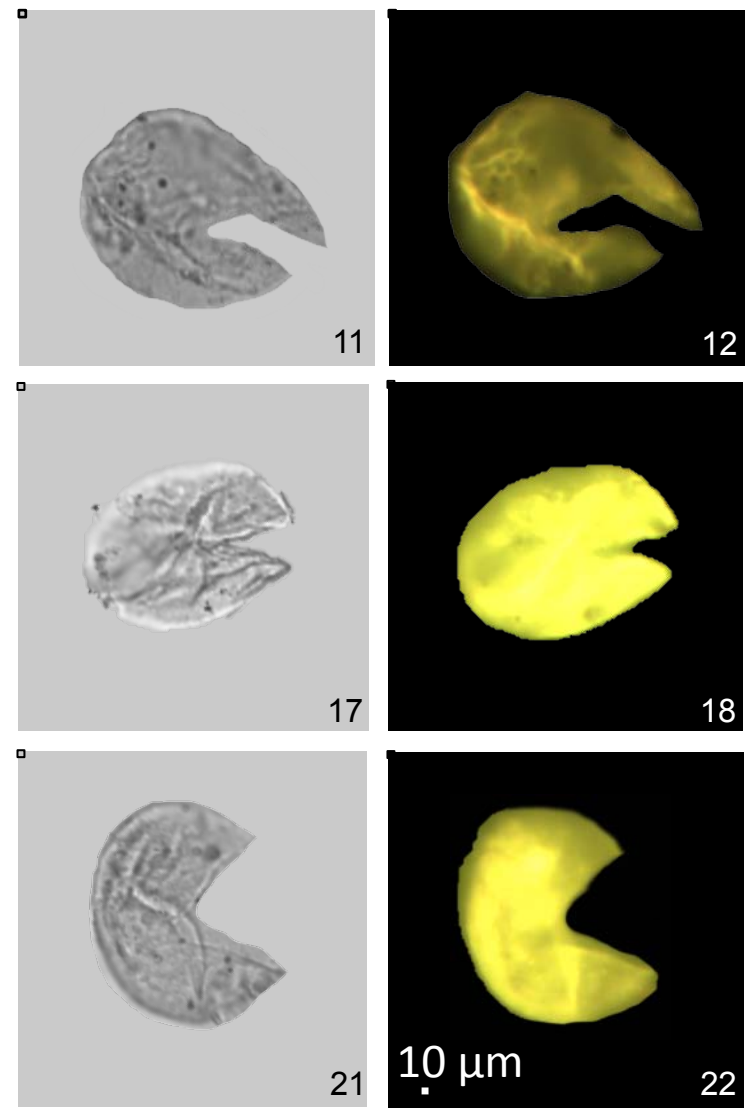
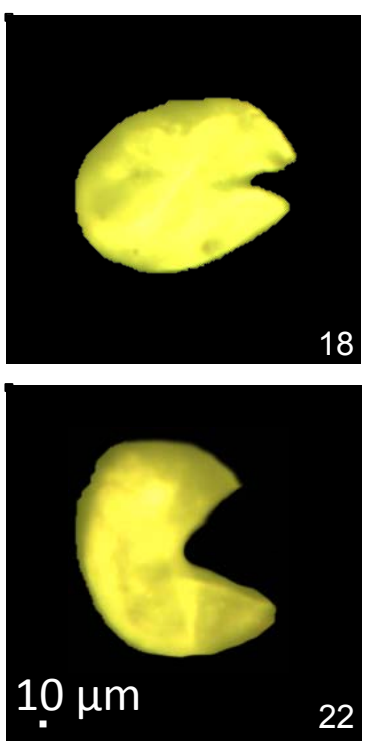

Plate II. Comparative examination of some Taxodiaceae and Artemisia fossil pollen grains in light and fluorescence microscopy. Scale-bar $=10 \mu \mathrm{m}$ for all the views.

1-8, at $2 \mathrm{~m}$ depth: 1, Taxodiaceae in light microscopy; 2, Same Taxodiaceae pollen in fluorescence microscopy; 3, Artemisia in light microscopy; 4, Same Artemisia pollen in fluorescence microscopy; 5, Taxodiaceae reworked pollen in light microscopy; 6, Same Taxodiaceae reworked pollen in fluorescence microscopy.

7-10, at $30.51 \mathrm{~m}$ depth: 7, Taxodiaceae in light microscopy; 8, Same Taxodiaceae pollen in fluorescence microscopy; 9, Artemisia in light microscopy; 10, Same Artemisia pollen in fluorescence microscopy.

11-12, at $49.47 \mathrm{~m}$ depth: 11, Taxodiaceae reworked pollen in light microscopy; 12, Same Taxodiaceae reworked pollen in fluorescence microscopy.

13-18, at 169.16 m depth: 13, Taxodiaceae in light microscopy; 14, Same Taxodiaceae pollen in fluorescence microscopy; 15, Artemisia in light microscopy; 16, Same Artemisia pollen in 
fluorescence microscopy; 17, Taxodiaceae in light microscopy; 18, Same Taxodiaceae pollen in fluorescence microscopy.

19-20, at 334.50 m depth: 19, Taxodiaceae in light microscopy; 20, Same Taxodiaceae pollen in fluorescence microscopy.

21-22, at fluorescer

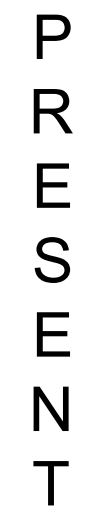

LOWER PLIOCENE

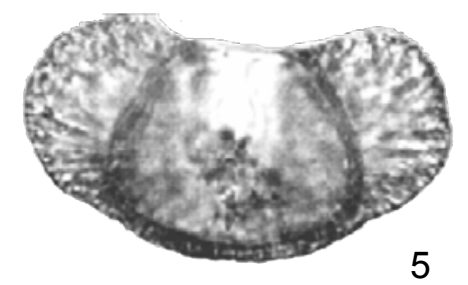

5
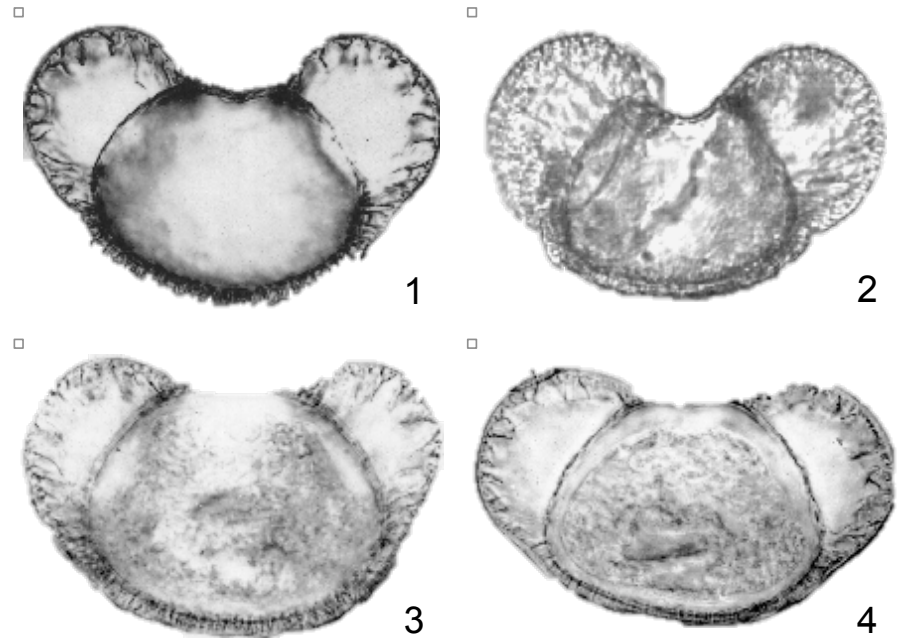

4

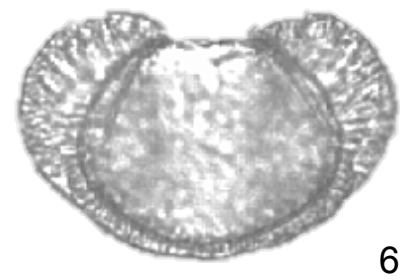

6

$\begin{array}{cc} & \text { U } \\ \text { M } & \text { P } \\ & \text { P } \\ \text { I } & \text { E } \\ & \text { R } \\ & - \text { M } \\ \text { O } & \text { I } \\ & \text { D } \\ \text { C } & \text { D } \\ & \text { L } \\ \text { E } & \text { E } \\ & \\ & \text { L } \\ \text { N } & O \\ & \text { W } \\ \text { E } & \text { E } \\ & \text { R }\end{array}$
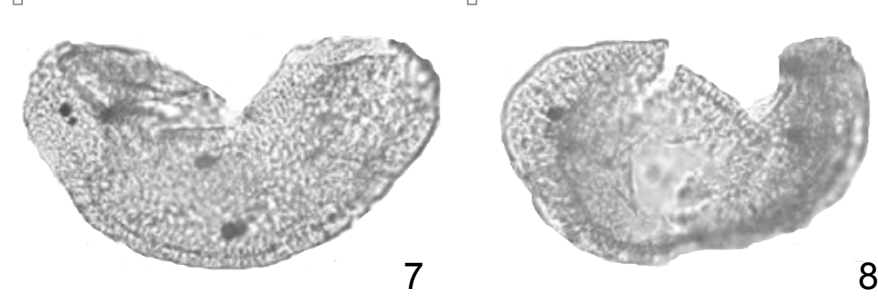

8

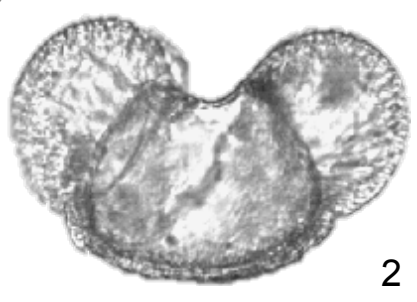

\section{2}

eae pollen in 
1-4, Pollen grains of the four living species: 1, C. libani A. Rich.; 2, C. brevifolia (Hook. f.) Henry; 3, C. deodara (Roxb.) G. Don.; 4, C. atlantica (Endl.) Manetti. ex Carrière. Photographs have been taken by one of us (J.-P.S.) from pollen slides of the ISEM collection (Montpellier) corresponding to plant samples indicated by Aytuğ (1961).

5-12, Fossil pollen grains from several localities: 5-6, Site 380 (Zanclean); 7-8, İntepe (latest Messinian); 9, Çatakbağyaka (middle Miocene); 10, Seyitömer (middle Miocene); 11-12, Ermenek (Aquitanian).

The scale-bar, shown in picture 12 , is the same for all the views. 